INTER NATIONAL MONETARY FUND

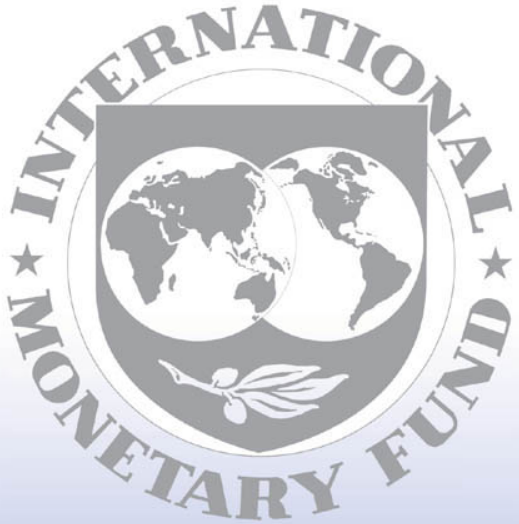

Staff

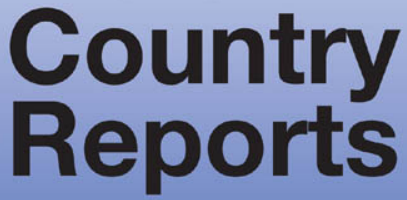




\section{Spain: The 2000 Article IV Consultation-Staff Report; Supplement to the Staff Report; Public Information Notice Following Consultation; and Statement by the Authorities of Spain}

As required under Article IV of its Articles of Agreement, the International Monetary Fund conducts periodic consultations with its member countries. In the context of the 2000 Article IV consultation with Spain, the following documents have been released and are included in this package:

- the staff report for the 2000 Article IV consultation, prepared by a staff team of the IMF, following discussions that ended on July 20, 2000, with the officials of Spain on economic developments and policies. Based on information available at the time of these discussions, the staff report was completed on September 29,2000 . The views expressed in the staff report are those of the staff team and do not necessarily reflect the views of the Executive Board of the IMF.

- a staff statement or supplement dated October 18, 2000, updating information on recent economic developments.

- the Public Information Notice (PIN), which summarizes the views of the Executive Board as expressed during the October 20, 2000, Executive Board discussion of the staff report that concluded the Article IV consultation.

- a statement by the authorities of Spain.

Further background documentation prepared by IMF staff for the consultation may be published separately at a later date. The policy of publication of Article IV staff reports and PINS allows for the deletion of market-sensitive information.

The Article IV staff report is published-both in hard copy and on the IMF's website (http://www.imf.org)-as part of a pilot project.

Copies of this report are available to the public from

International Monetary Fund - Publication Services

700 19th Street, N.W. • Washington, D.C. 20431

Telephone: (202) 6237430 - Telefax: (202) 6237201

E-mail: publications@imf.org • Internet: http://www.imf.org

Price: $\$ 15.00$ a copy

International Monetary Fund

Washington, D.C. 


\section{INTERNATIONAL MONETARY FUND}

SPAIN

Staff Report for the 2000 Article IV Consultation

Prepared by the Staff Representatives for the 2000 Consultation with Spain Approved by Michael Deppler and G. Russell Kincaid

September 29, 2000

- Consultation discussions were held in Madrid during July 6-20, 2000.

- The staff team comprised Messrs. Watson (head), Gerson, Mesquita (all EU1), and Spilimbergo (RES). Mr. Pascual and Ms. Fernández (OED) participated in the meetings.

- The team met with Deputy Prime Minister and Minister of Economy Rato, Minister of Finance Montoro, Bank of Spain Governor Caruana, and other senior officials of the government, the Bank of Spain, the regional government of Andalucia, and the municipal government of Seville. It also met with representatives of private sector organizations-including the employers' association and financial institutions-and labor unions.

- Spain is a founding member of the euro and maintains an exchange system free of restrictions on the making of payments and transfers for current international transactions (Appendix III).

- Spain has subscribed to the Special Data Dissemination Standard, and has accepted the obligations of Article VIII, Sections 2, 3, and 4 (Appendix IV).

- The authorities have indicated their intention to publish the staff report. 


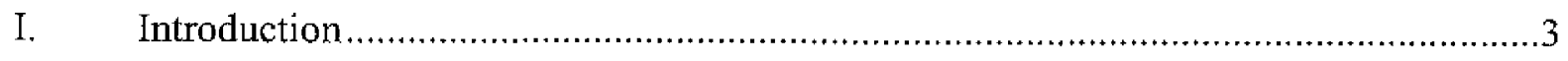

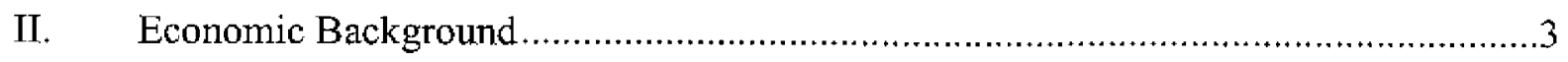

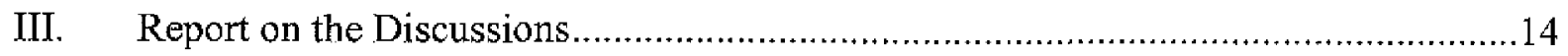

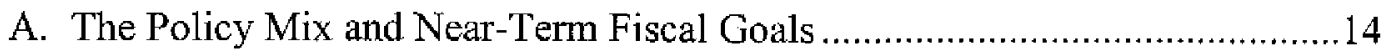

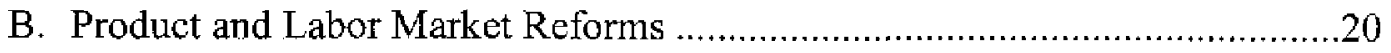

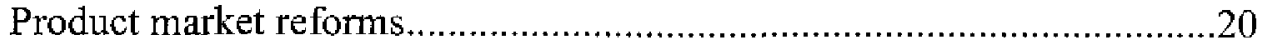

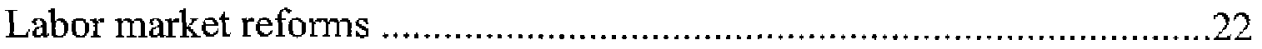

C. Medium- and Long-Term Challenges for the Public Finances ..................24

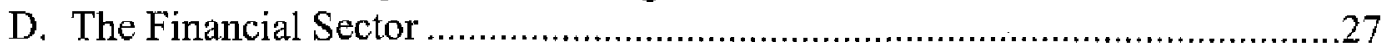

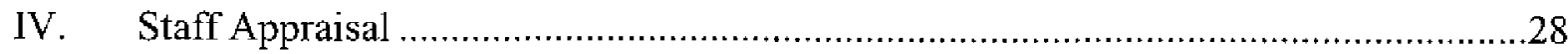

Text Boxes

1. Cyclically Advanced Euro-Area Economies: Consequences and Policy Options......18

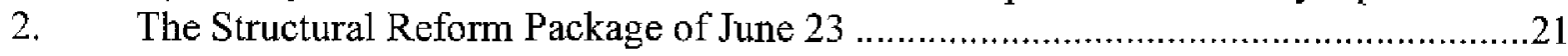

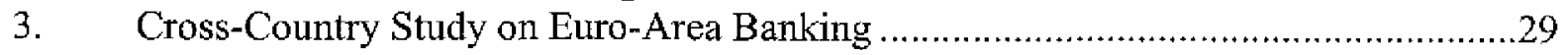

Figures

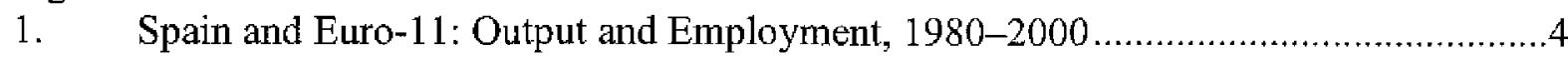

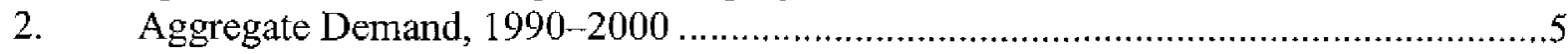

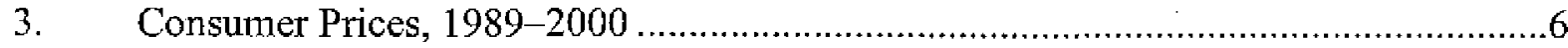

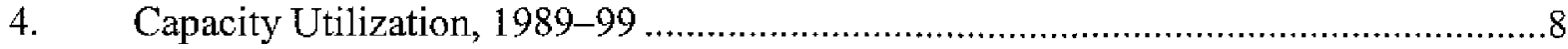

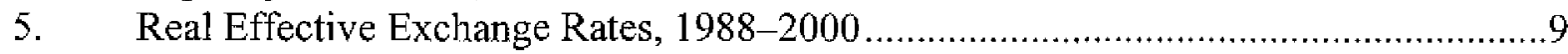

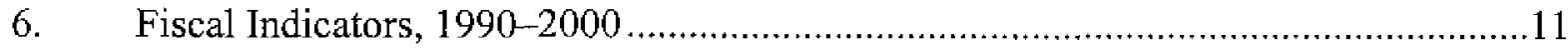

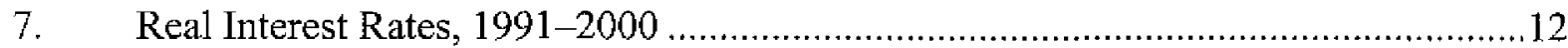

8a. Selected Countries: Composition of Fiscal Adjustment, 1995-99 ....................15

8b. Selected Countries: Composition of Fiscal Adjustment, 1995-99 ........................16

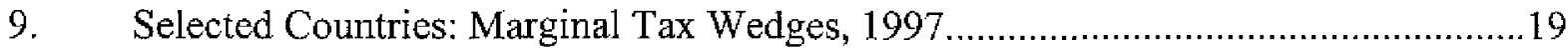

Tables

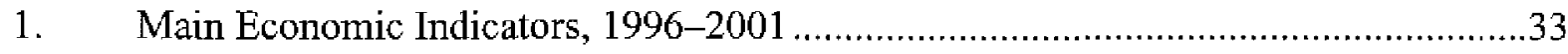

2. Medium-Term Fiscal Scenario on Present Policies, 1996-2003 .............................34

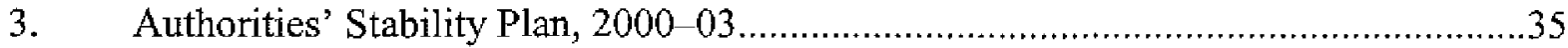

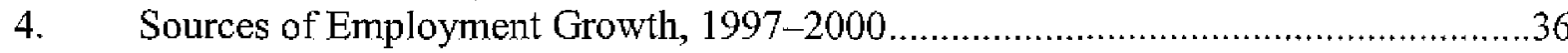

5. Indicators of External and Financial Vulnerability, 1995-2000 _..........................37

Appendices

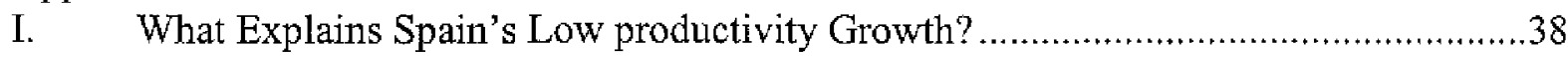

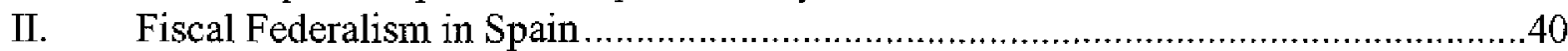

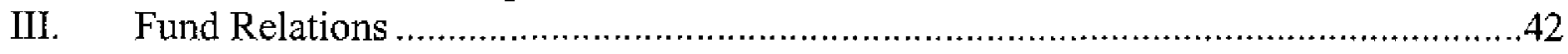

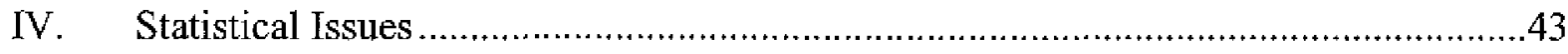




\section{INTRODUCTION}

1. The last Article IV consultation was concluded on June 30, 1999, Directors praised the sound macroeconomic policies that had culminated in Spain's founding membership in the euro area. They supported the medium-term goals of the authorities' Stability Program, but urged readiness to tighten fiscal policy in the near term should inflationary pressures mount. Recognizing high unemployment to be Spain's most pressing social problem, they advised extending labor and product market liberalization to stimulate employment growth.

2. In March the Popular Party government of Prime Minister Aznar was returned to power with an outright parliamentary majority. The Ministry of Finance and Economy has been split, with Deputy Prime Minister Rato-the former Minister-named Minister of Economy, and former Secretary of State for the Economy Montoro taking the reins at the Ministry of Finance. Jaime Canuana was appointed governor of the Bank of Spain in July.

\section{ECONOMIC BACKGROUND}

3. Spain has achieved impressive growth in recent years-reflecting favorable competitiveness, and the impact on interest rates and confidence of its successful road to monetary union. Real export growth of more than 12 percent annually in 1995-97, combined with a sharp fall in interest rates, boosted profitability, and thus investment. In a setting of notable wage moderation, employment expanded strongly, and the resulting rise in household income spurred consumption growth. Over the past three years, real GDP growth has fluctuated narrowly, averaging more than 4 percent. A slight easing of domestic demand since early 1999 has thus far been offset by a renewed acceleration of exports (Figures 1 and 2, Table 1), and in Q1 and Q2 2000, real GDP showed an increase of 4.2 percent (yearon-year).

4. Despite several years of rapid growth, there are no unambiguous signs of overheating:

- Underlying inflation has varied within a range of 2 and $2^{3 / 4}$ percent on a $12-$ month basis since January 1997 , but has exceeded the euro-area average (Figure 3 ). In August it stood at 2.7 percent, $1 \frac{1}{2}$ percentage points above the euro-area average. In particular, rates of inflation for nontraded goods (services) have typically been double the euro-area average. Data on productivity growth (Appendix I) do not support the hypothesis that Spain's relatively high inflation rate is arising from the convergence process, but there are concerns about their accuracy. Given these concerns about the data on productivity-and particularly employment - it is hard to take the analysis further. On the one hand, it is clearly plausible that the rate of inflation in the services sector in part reflects demand pressures; on the other, as Spain's per capita income level converges toward the EU average, from a level some 20 percent below, there could be scope for convergence and Balassa-Samuelson effects to influence the rate of CPI inflation in the manner observed in other countries in analogous positions, such as Ireland. 
Figure 1. Spain and Euro-11: Output and Employment, 1980-2000

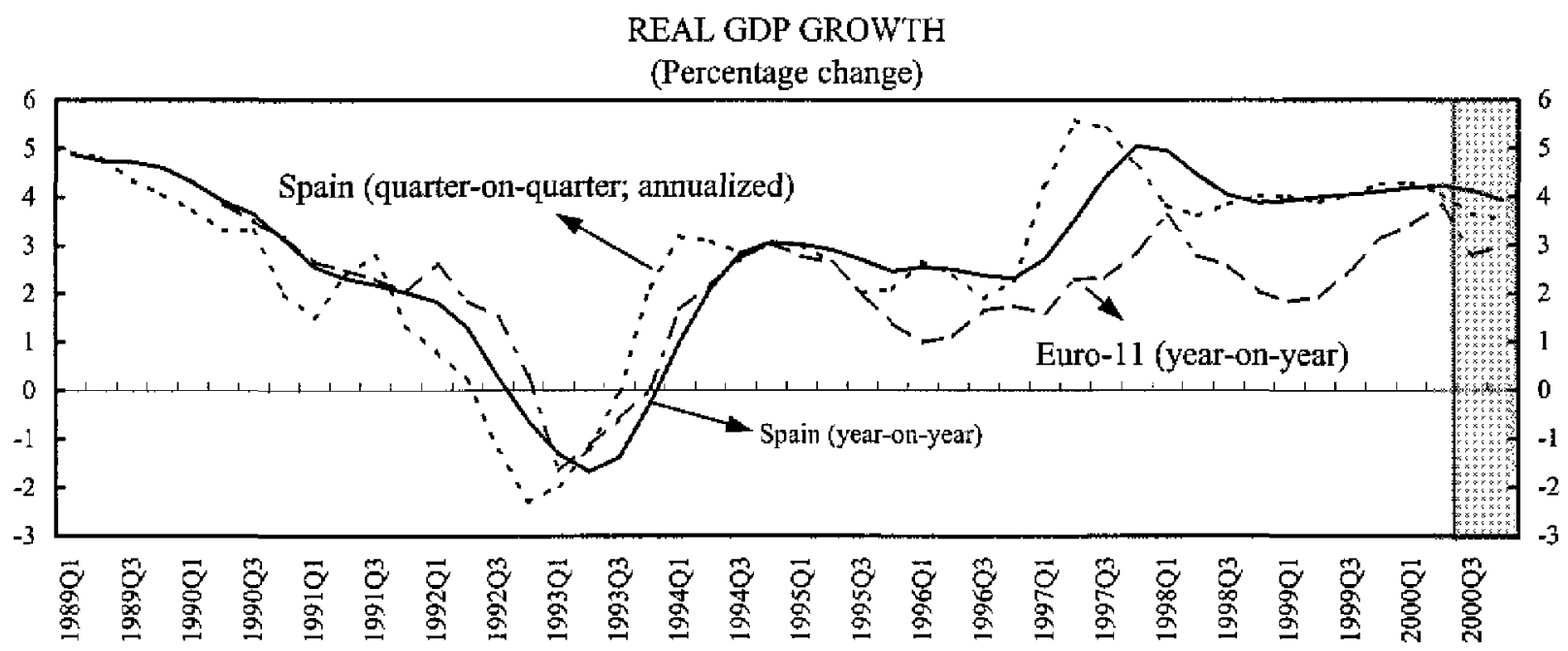

UNEMPLOYMENT RATES

(In percent)

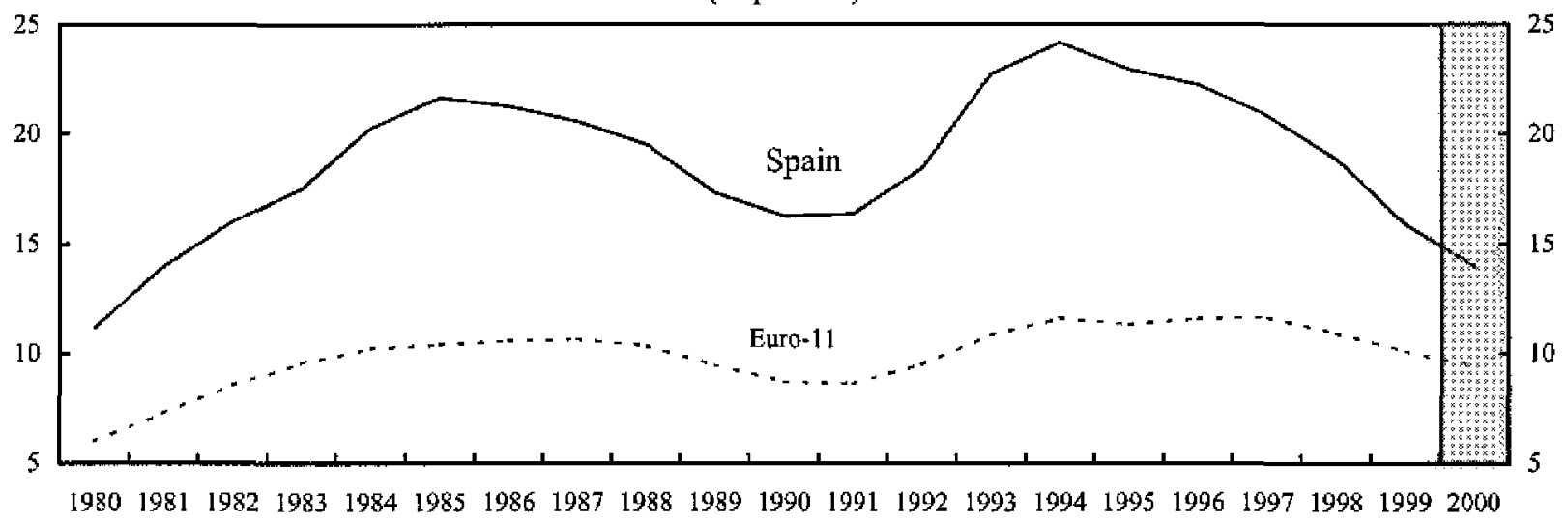

EMPLOYMENT

(Annual percentage change)

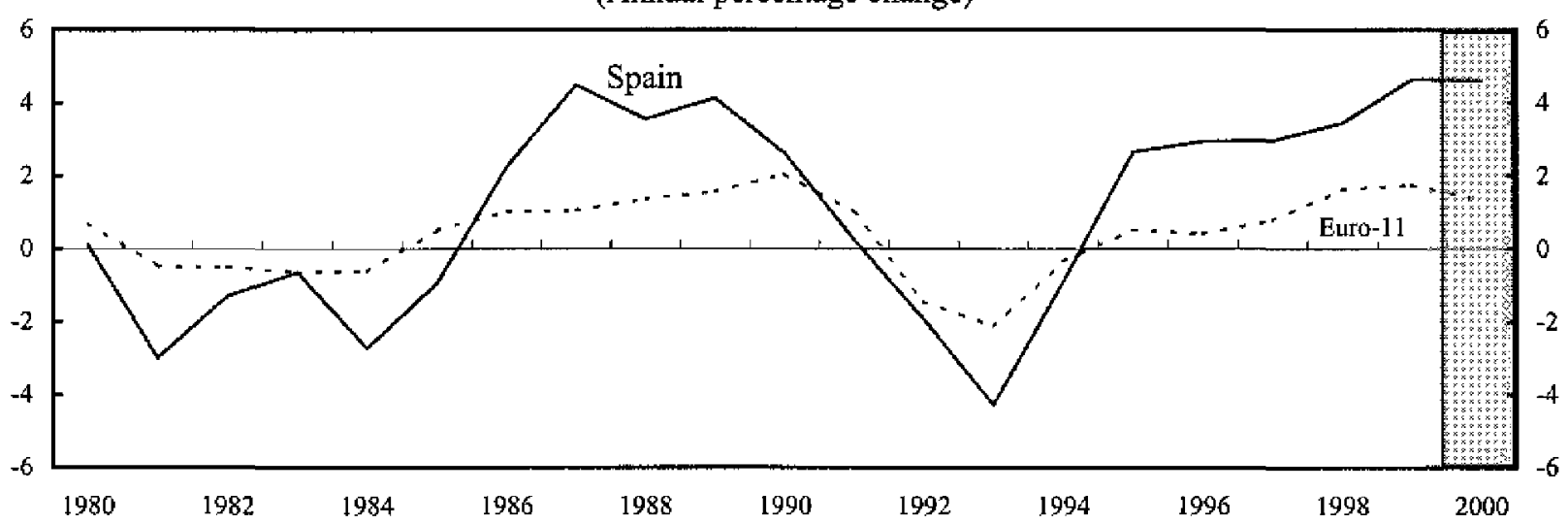

Sources: Bank of Spain; Bloomberg; and Fund staff projections. 
Figure 2. Spain: Aggregate Demand, 1990-2000

PRIVATE CONSUMPTION

(Year-on-year percentage change)

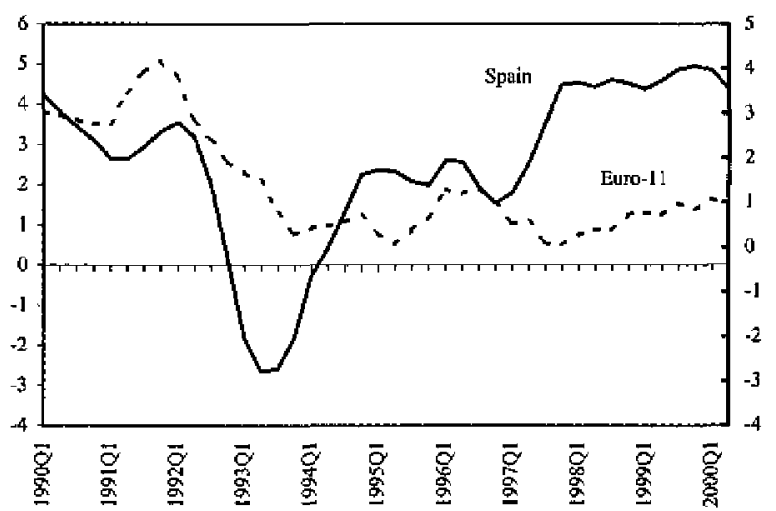

EXTERNAL CONTRIBUTION

(In percent of GDP)

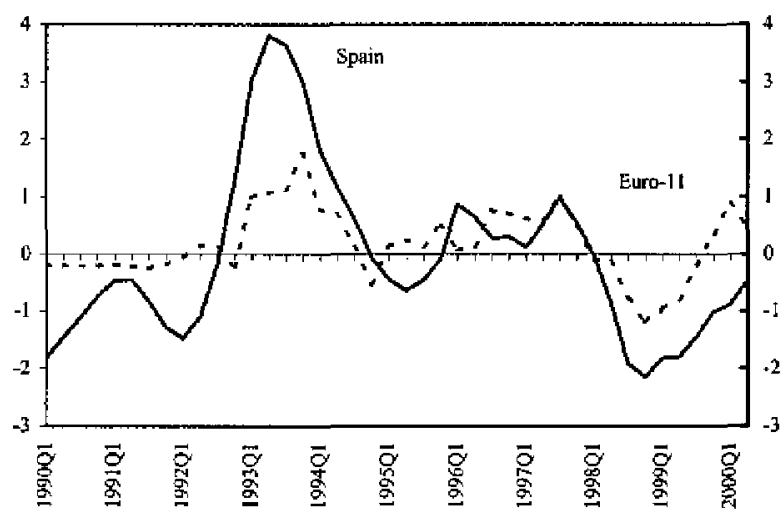

GROSS FIXED INVESTMENT

(Year-on-year percentage change)

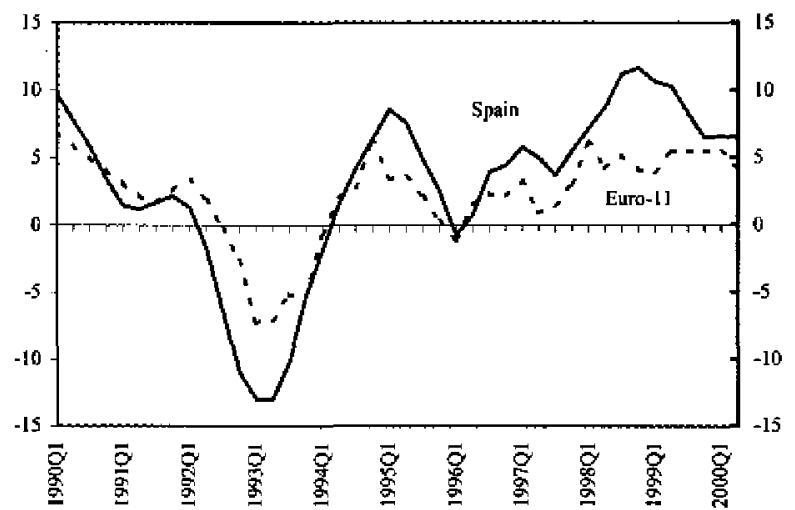

PUBLIC CONSUMPTION

(Year-on-year percentage change)

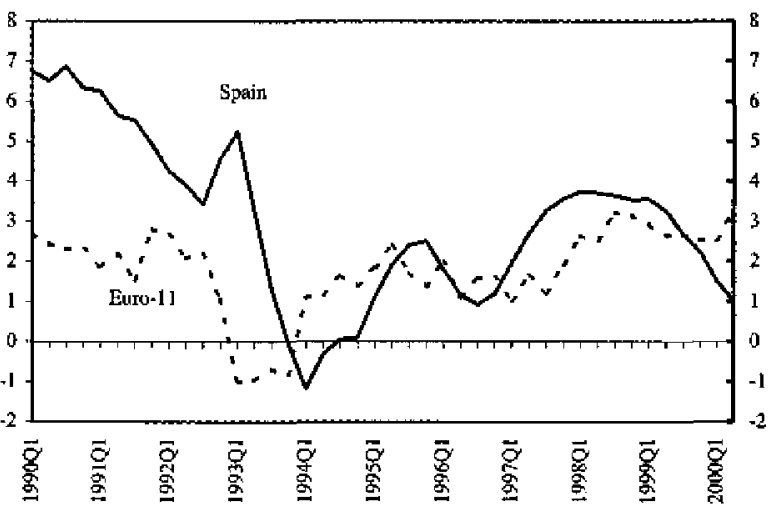

CONTRIBUTION OF STOCKS

(In percent of GDP)

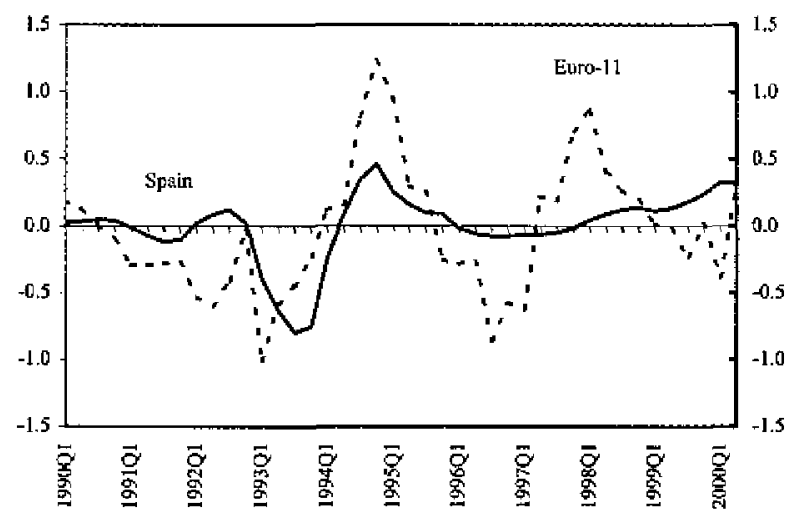

EQUIPMENT AND CONSTRUCTION INVESTMENT

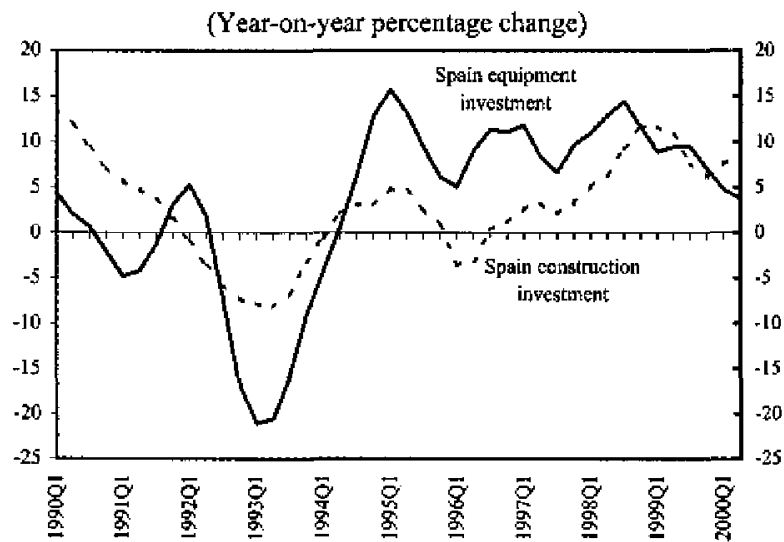

Sources: Bank of Spain; and Eurostat. 
Figure 3. Spain: Consumer Prices, 1989-2000

(Year-on-year percentage change)

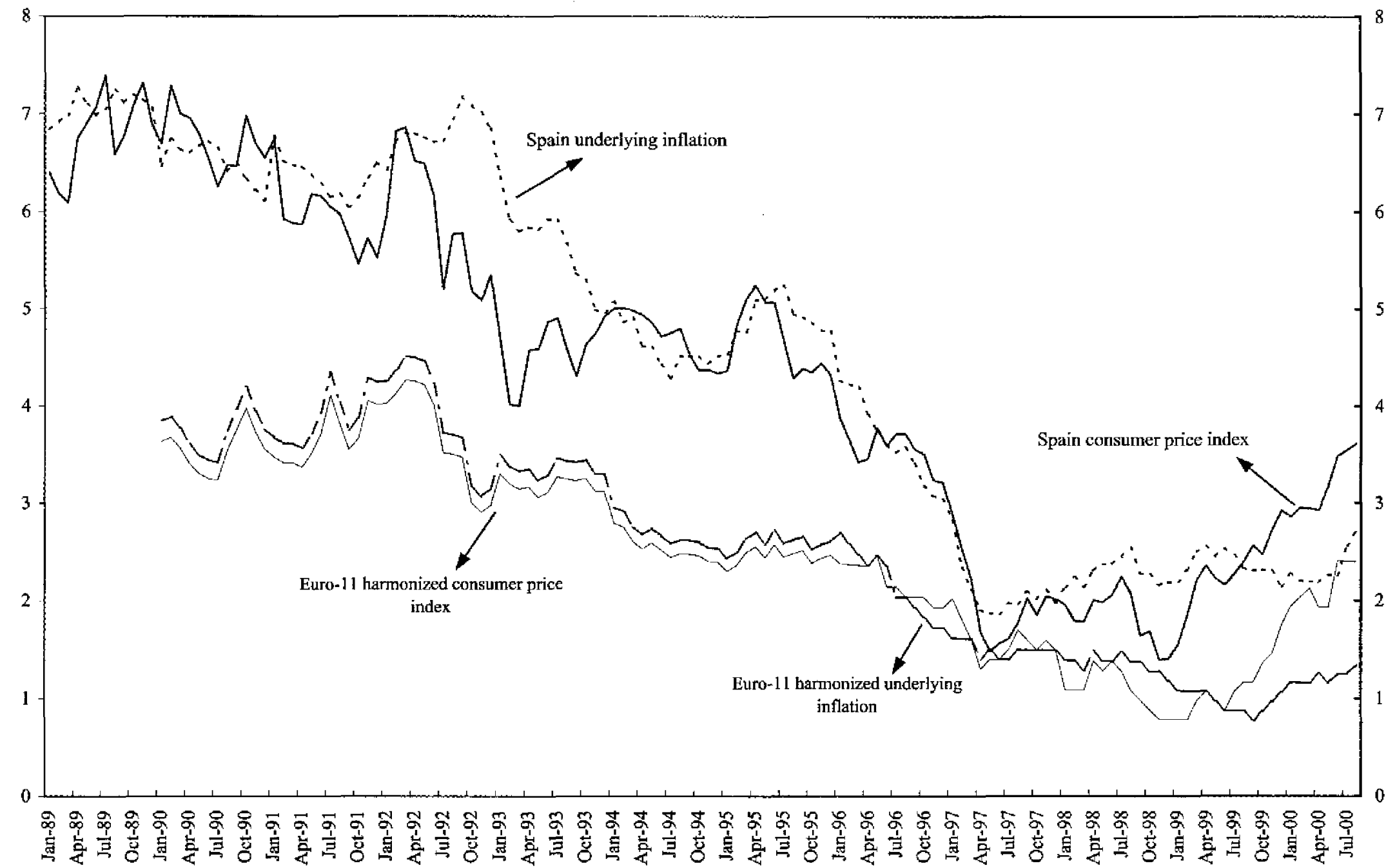

Sources: Bank of Spain; and Eurostat. 
- Three years of steeply falling unemployment have yet to trigger a material acceleration of labor costs. New contract wages rose by 3 percent annually through August 2000 , against $2 \frac{1 / 2}{2}$ percent in 1999 . While recorded unit labor costs in manufacturing rose by some 2 percent annually over the last three years, compared to an average decline of about $3 / 4$ percent in the euro area as a whole, concerns about data on productivity growth affect these calculations. Producer prices in manufacturing accelerated steadily during 1999-but this reflected higher oil prices and euro depreciation, and has recently tapered off. In July producer price inflation stood at $5 \frac{1}{2}$ percent, equal to the euro-area average. Profitability remains strong, partly due to lower financing costs.

- While unemployment has fallen sharply, to its lowest level in two decades (Figure 1), it is higher than in other advanced economies, and participation is very low. Employment growth of 3-41/2 percent annually since 1995 has cut the unemployment rate from over 24 percent in 1994 to 14 percent in June 2000. However, this in part reflects movement out of the informal sector, as a result of reforms. Participation has risen marginally, but fully half of the population over 15 remains out of the formal labor force, against an EU average of one-third, suggesting potentially high spare labor capacity (although significant training may be required for some of these individuals).

- While most estimates suggest that output is close to or at potential, and capacity utilization in manufacturing has been at record levels since mid-1998 (Figure 4), recent structural reforms may have raised the headroom for growth. At a minimum, the recent stability of underlying and service sector inflation raises questions about these estimates. Staff work aimed at estimating jointly the NAIRU and the output gap suggests, on a preliminary basis, a small output gap at end-1999. Even these estimates may not fully capture the impact of recent structural and labor market reforms.

- The external current account moved from balance to a deficit of over 2 percent of GDP in 1999, and of $23 / 4$ percent in January-June 2000, but competitiveness in world markets remains strong, owing in part to the weak euro. Both CPI- and ULC-based real effective exchange rates remain at their levels following the devaluations of 1992-93 (Figure 5), although this reflects to some extent the recent level of the euro. ${ }^{1}$ Exporters continue to gain market share, and FDI inflows since 1998 have been some 80 percent above the level of the previous three years, suggesting that Spain remains an attractive environment. During January-June 2000, export volumes grew by $12^{3 / 4}$ percent (year-on-year).

Nonetheless, with some uncertainty about data on unit labor costs, and risks of a wage catchup down the line, questions remain about competitiveness over the medium term-especially if the euro were to appreciate strongly.

\footnotetext{
${ }^{1}$ Though 60 percent of exports go to the euro area a 3.6 percent depreciation of the nominal effective exchange rate in 1999 offset the rise in Spain's relative unit labor costs in the year.
} 
Figure 4. Spain: Capacity Utilization, 1989-99

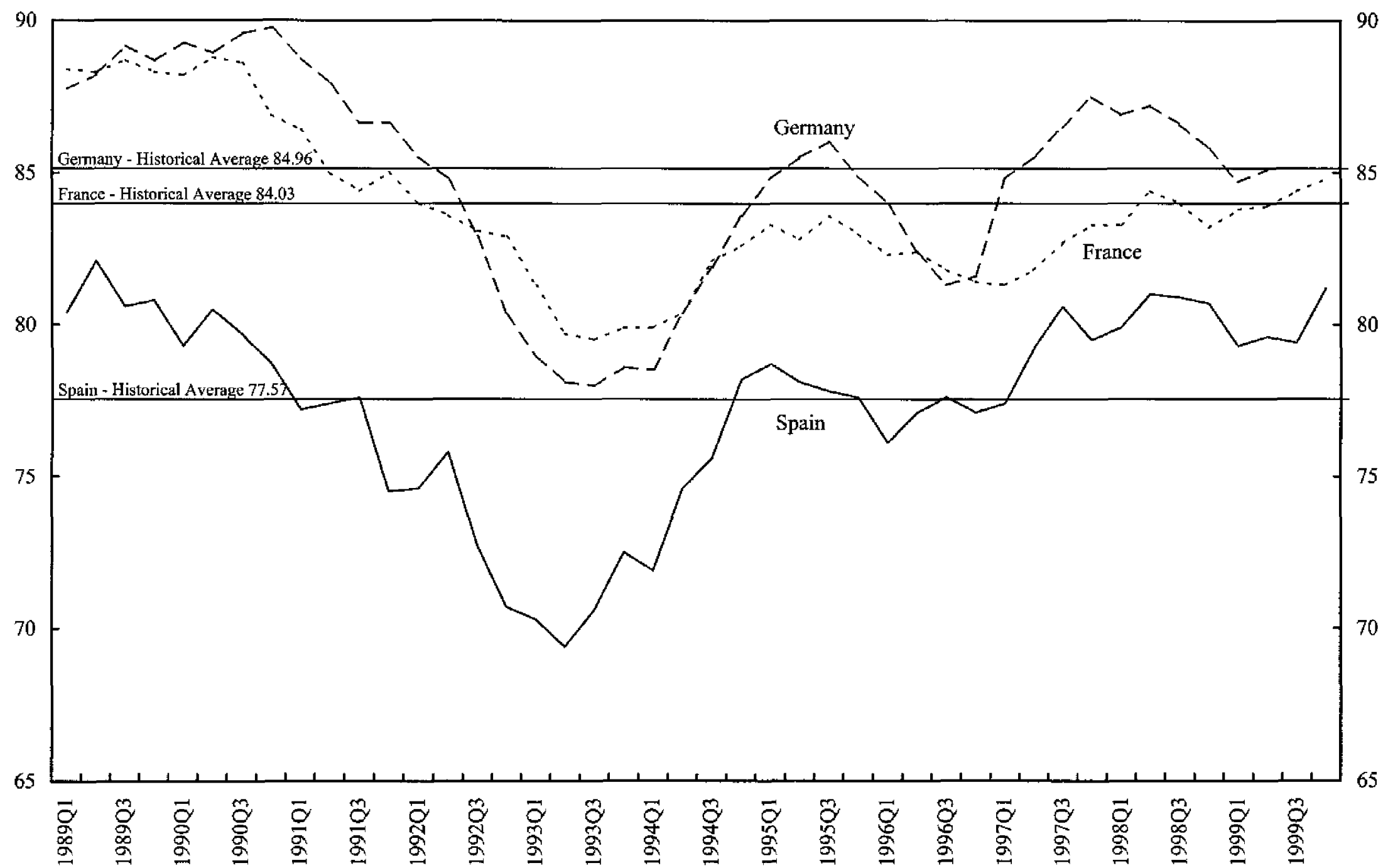

Sources: Bank of Spain; and WEFA. 
Figure 5. Spain: Real Effective Exchange Rates, 1988-2000

(Index 1990=100)

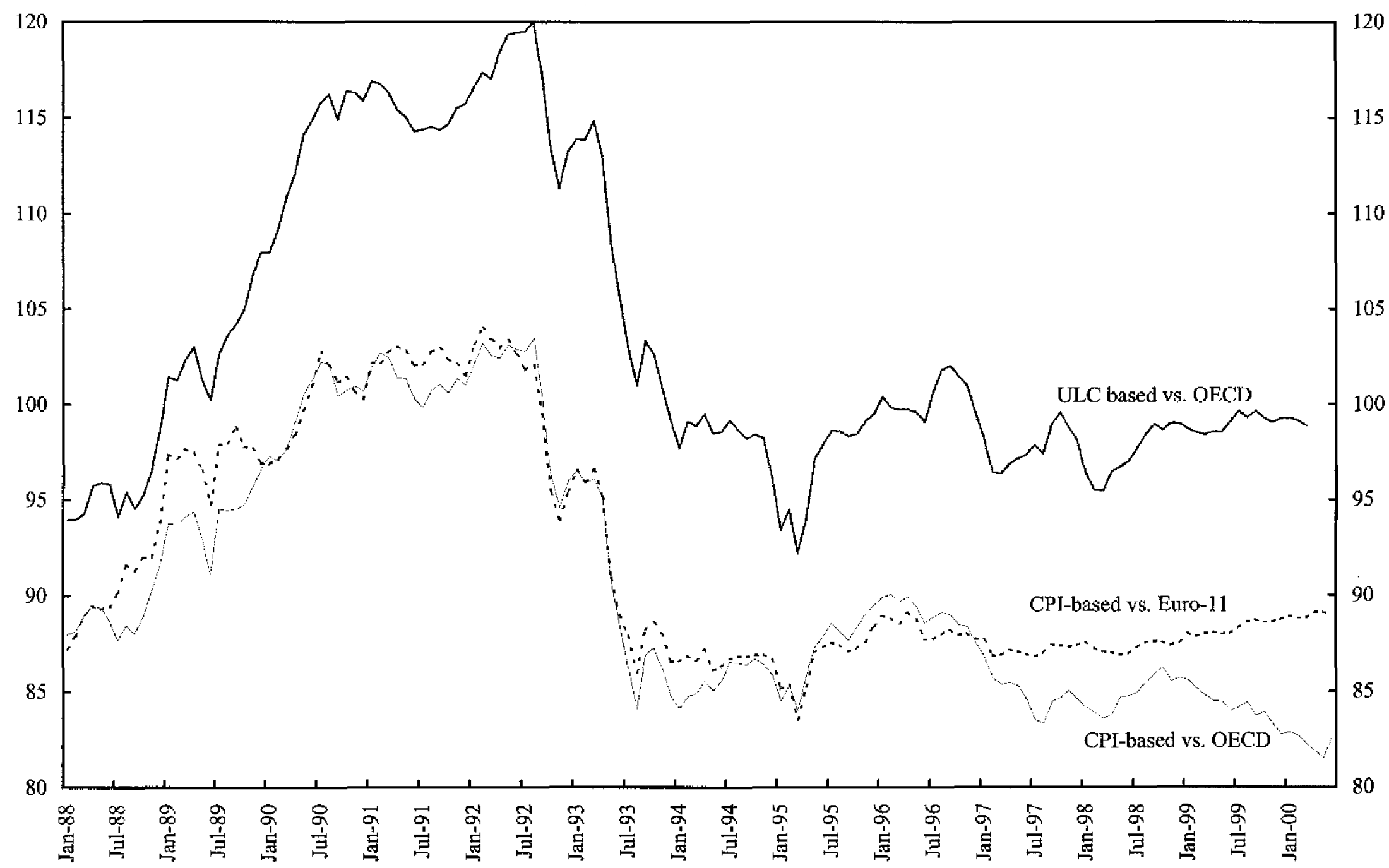

Sources: Bank of Spain; and IMF, Information Notice System. 
- Asset price inflation has been much lower than in some other cyclicallyadvanced euro-area economies, and asset prices appear broadly consistent with fundamentals. Housing prices rose by 8 percent annually between the first quarters of 1997 and 2000 . Stock market prices performed more strongly, with the IBEX-35 rising by 17 percent annually since August 1997-still well below the rise in EU-wide indices such as the Euro Stoxx 50 (25 percent annually since August 1997). The recent WEO study found that growth in Spanish stock market values could be explained by changes in fundamentals.

- Bank credit to the private sector has increased significantly in the last three years, but this reflects in part a stock adjustment to lower real interest rates. Credit grew by close to 16 percent in the 12 months to July, about equal to the annual average for 1997-99. The share going to real estate rose from 24 percent in 1995 to 31 percent in the second quarter of 2000 . However, overall levels of indebtedness remain moderate, and the stock of private sector bank debt--standing at about 90 percent of GDP-is now close to the euro-area average of 95 percent. A broader cross-country comparison of some possible indicators of overheating can be found in the accompanying background paper on cyclically advanced euro-area economies (SM/00/182).

5. Fiscal consolidation continues to run ahead of target. The overperformance in 1999 (a deficit of 1.1 percent of GDP, against a targeted 1.6 percent) reflected both revenue strength-particularly for VAT - and spending restraint. The expenditure ratio fell by 1 percentage point to 41.1 percent of GDP, mainly as a result of lower interest expense and unemployment benefits, and a continued compression of the state budget salary bill (Table 2). (For several years, the central government has replaced only one-fourth of departing civil servants.) Official Development Assistance was 0.23 percent of GDP-equal to the average for the period 1995-98 - compared to the UN target of 0.7 percent. In 2000 , again, fiscal consolidation is running ahead of track. While the budget aimed for a deficit of 0.8 percent of GDP, with increased spending on active labor market policies and minimum pensions, the authorities in June announced a revised target of 0.4 percent, reflecting the strength of the economy and additional spending restraint. It appears likely that, with revenues continuing to be buoyant, there will be a fiscal withdrawal in 2000 of up to $1 / 4$ percent of GDP (Figure 6$)^{2}$

\section{Monetary conditions, already very accommodative from a purely Spanish} perspective, on balance eased further through mid-2000. Although real short-term interest rates increased in line with ECB policy rates (Figure 7), the continuing depreciation of Spain's real effective exchange rate left monetary conditions, as of July, at their most accommodative level in years. Monetary conditions appear unduly accomodative in relation

\footnotetext{
${ }^{2}$ Estimates of the fiscal impulse and structural balance exclude the impact of the awarding of UMTS licenses (equal to 0.1 percent of GDP).
} 
Figure 6. Spain: Fiscal Indicators, 1990-2000

GENERAL GOVERNMENT BALANCE

(In percent of GDP)

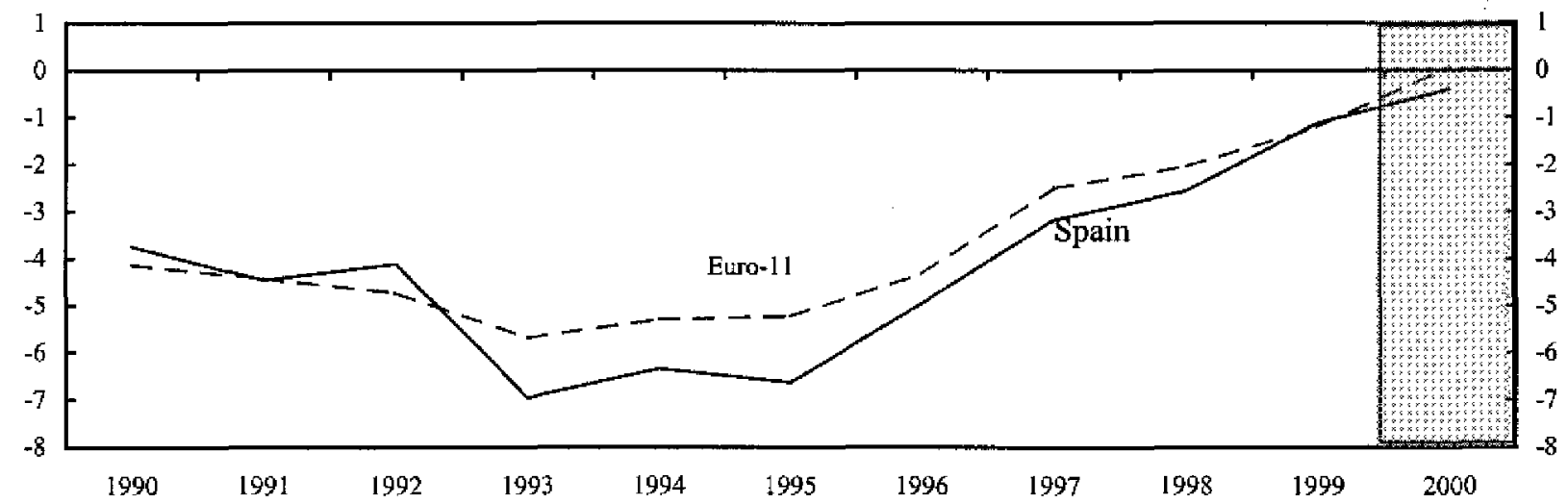

GENERAL GOVERNMENT STRUCTURAL BALANCE

(In percent of potential output)

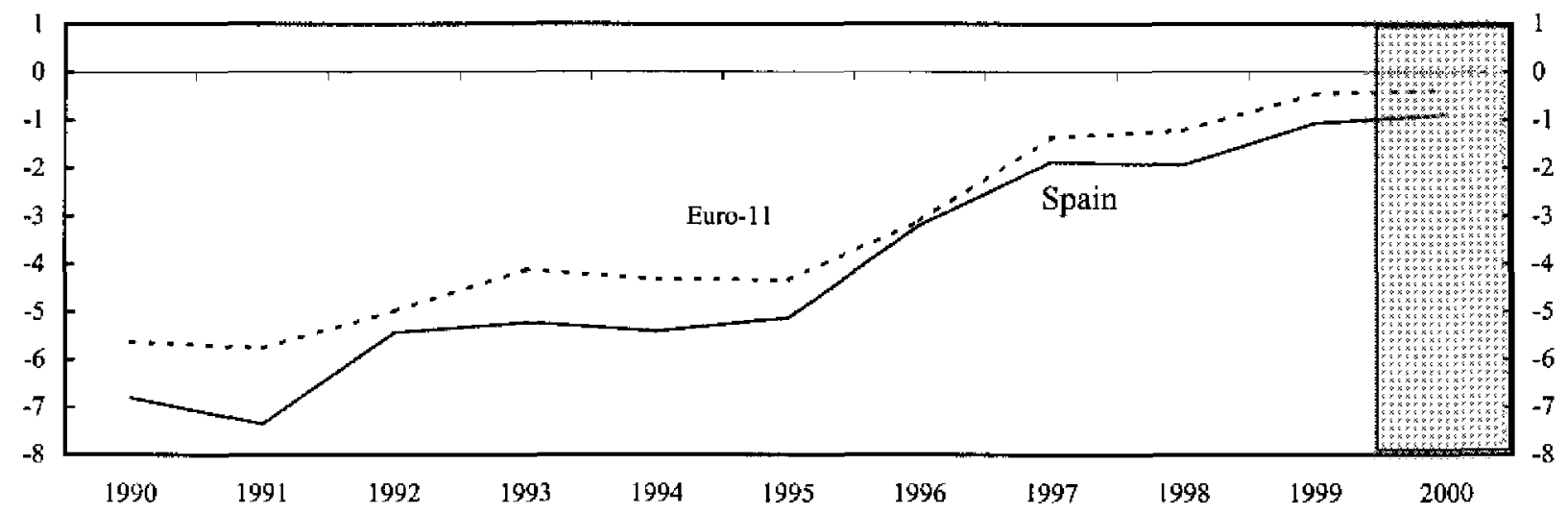

GENERAL GOVERNMENT PRIMARY STRUCTURAL BALANCE

(In percent of potential output)

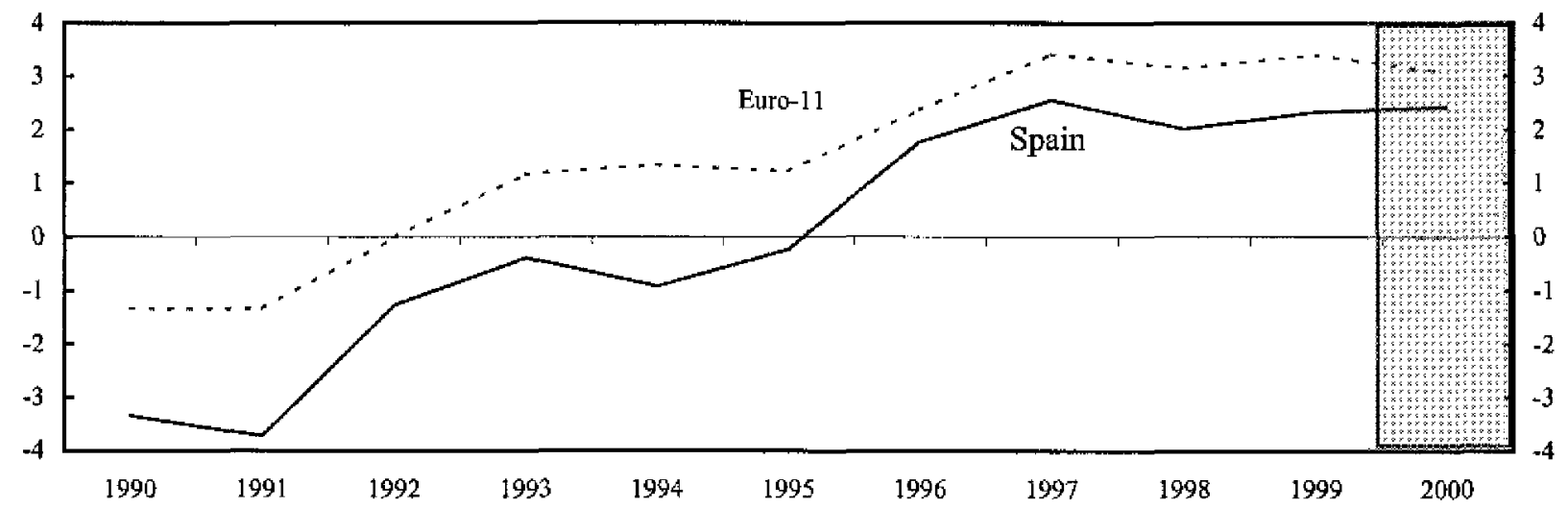

Sources: World Economic Outlook; and Fund staff projections. 
Figure 7. Spain: Real Interest Rates, 1991-2000

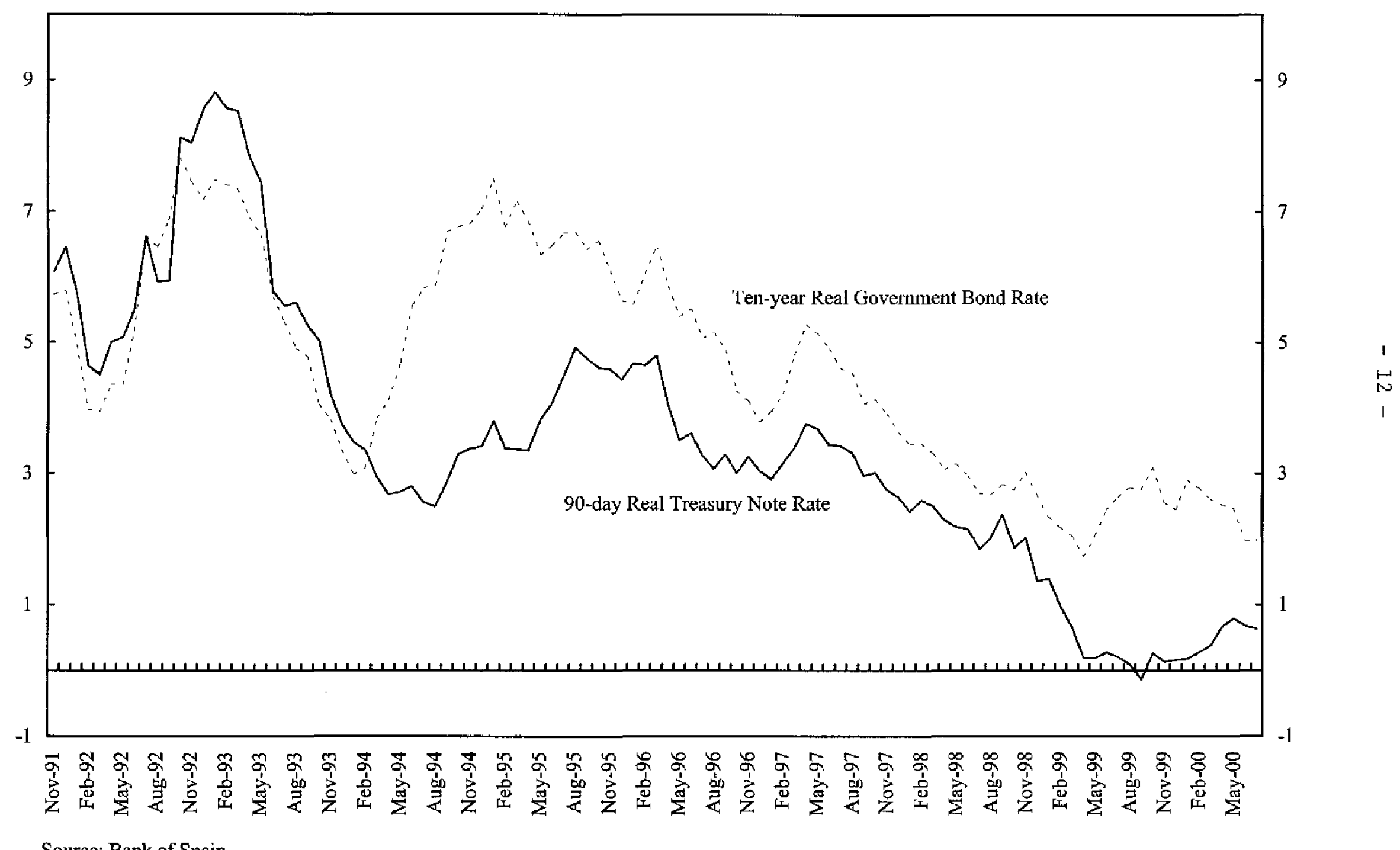

Source: Bank of Spain. 
to Spain's advanced cyclical position, and combined with the modest withdrawal of fiscal stimulus this year, overall macroeconomic conditions are expansionary. ${ }^{3}$

7. Growth is expected to remain strong. With GDP set to rise by at least 4 percent in 2000 , the question is whether growth will slow to about potential in 2001 (about $3 \frac{1 / 2}{2}$ percent). Recent quarters evidenced a moderation of domestic demand, but this was offset by net exports. In 2001, export strength is likely to persist, while domestic demand growth could taper further as the lagged stimulus from falling interest rates fades and reverses and fiscal withdrawal increases on at least on a modest scale (about $1 / 2$ percent of GDP on current policies), and if monetary conditions continue to tighten in line with market expectations. The recent slowdown in spending on durables should be extended as replacement activity eases and as the immediate impact of last year's personal income tax reform wears off. Spending on some durables (such as automobiles) has also been negatively affected by high oil prices. Overall, GDP growth could slow to some $31 / 2$ percent. Unemployment would fall to about $121 / 2$ percent by year-end. On this basis, as the impact of higher energy prices fades, headline CPI inflation should ease progressively from recent levels to average a little over 3 percent this year, and about $2 \frac{1}{2}$ percent in 2001 , about in line with current underlying inflation. At this level, the inflation differential relative to the euro-area average would narrow somewhat from its current level but would still average about $3 / 4$ percent in 2001 . These projections are consistent with the September Consensus Forecast. Should higherthan-expected headline inflation translate into a sharp increase in labor costs, or should monetary conditions turn more accomodative, this could result in higher underlying inflation in 2001 .

8. Risks are largely on the upside, absent an externally induced shock. Domestic demand could exceed expectations if employment growth accelerates, demand in the other euro-area economies could be stronger than expected, and a weak euro could stimulate export growth outside the common currency area. The main downside risk is an external shock, such as a sharp appreciation of the euro, or a sizable correction in U.S. equity markets. While wealth effects of the latter would likely be limited, it could have a negative impact on the financial sector, given the large shareholdings of major banks. A sharp and protracted downturn in Latin America could also have a negative effect on the Spanish financial sector, given the significant exposure of Spanish banks in that region. In addition, continued very high oil prices could dampen demand growth both within Spain and in key export markets.

\footnotetext{
${ }^{3}$ Simulations using the Oxford Economic Forecasting model suggest that a 100 basis point increase in short-term nominal interest rates has the same impact on GDP growth ( 0.4 percentage point) in the first year as a fiscal withdrawal of $1 / 2$ percent of GDP or an appreciation of the euro of 10-15 percent.
} 


\section{REPORT ON THE DISCUSSIONS}

9. There was agreement on the key challenges - to sustain the expansion, to reduce structural unemployment, and to address medium- and long-run issues in the public finances. The authorities, while seeing no clear-cut evidence of overheating, were alert to the risk that Spain's rate of inflation could threaten competitiveness, and thus the sustainability of the expansion, especially in a setting of euro appreciation. This added urgency to the medium- and long-run case for completing fiscal consolidation and deepening structural reforms, perhaps most critically in labor markets. It was also important to finalize fiscal decentralization and renew discussions on pensions. Recent reforms had delivered an unprecedented combination of output and employment growth, with price stability. Now, the authorities stressed, it was crucial not to fall into complacency, but to press on with reforms to extend this growth and job creation.

\section{A. The Policy Mix and Near-Term Fiscal Goals}

10. The authorities underscored that fiscal consolidation had been a cornerstone of Spain's economic success. Between 1996 and 1999, the fiscal deficit was cut by 4 percent of GDP. Moreover, qualitative reforms had reduced the gap between spending on a cash and a commitment basis and limited excess tax withholding. State and local governments also strengthened spending control and had contributed to consolidation under Spain's internal stability pact, which spells out deficit targets for each element of the general government. These actions had been a driving force improving economic confidence and enhancing policy credibility. Notably, Spain had achieved larger increases in its primary surplus than some of the larger euro area countries, and had relied less on revenue increases to do so (Figures 8a and $8 \mathrm{~b}$ ). The authorities affirmed, however, that past restraint had placed limits on needed public investment.

11. The authorities and staff agreed that monetary conditions were too accommodative from a purely Spanish perspective. While recognizing that market expectations are for a further rise in interest rates as recovery in the core countries continues, the authorities noted that monetary conditions would likely remain unduly easy for the domestic economy, absent a significant appreciation of the euro. Nonetheless they expected that the maturation of the durable goods cycle, the fiscal withdrawal, and the continued increase in real interest rates would lead to a moderate decline in growth next year to about $3 \frac{1}{2}$ percent (in line with the staff's estimate), while acknowledging risks might be on the upside.

12. This triggered a discussion of whether policy should now aim for increasing fiscal surpluses to offset easy monetary conditions. The authorities noted several points:

- Their plans to accelerate fiscal consolidation in 2000 and 2001 were motivated in significant part by longer-term and structural concerns. In addition to halving the 2000 deficit target to 0.4 percent of GDP, they had announced plans to achieve fiscal balance in 2001, one year ahead of the schedule established in their Stability Program (Table 3). This 
Figure 8a. Selected Countries: Composition of Fiscal Adjustment, 1995-1999 1/

(Cumulative change, in percent of GDP)
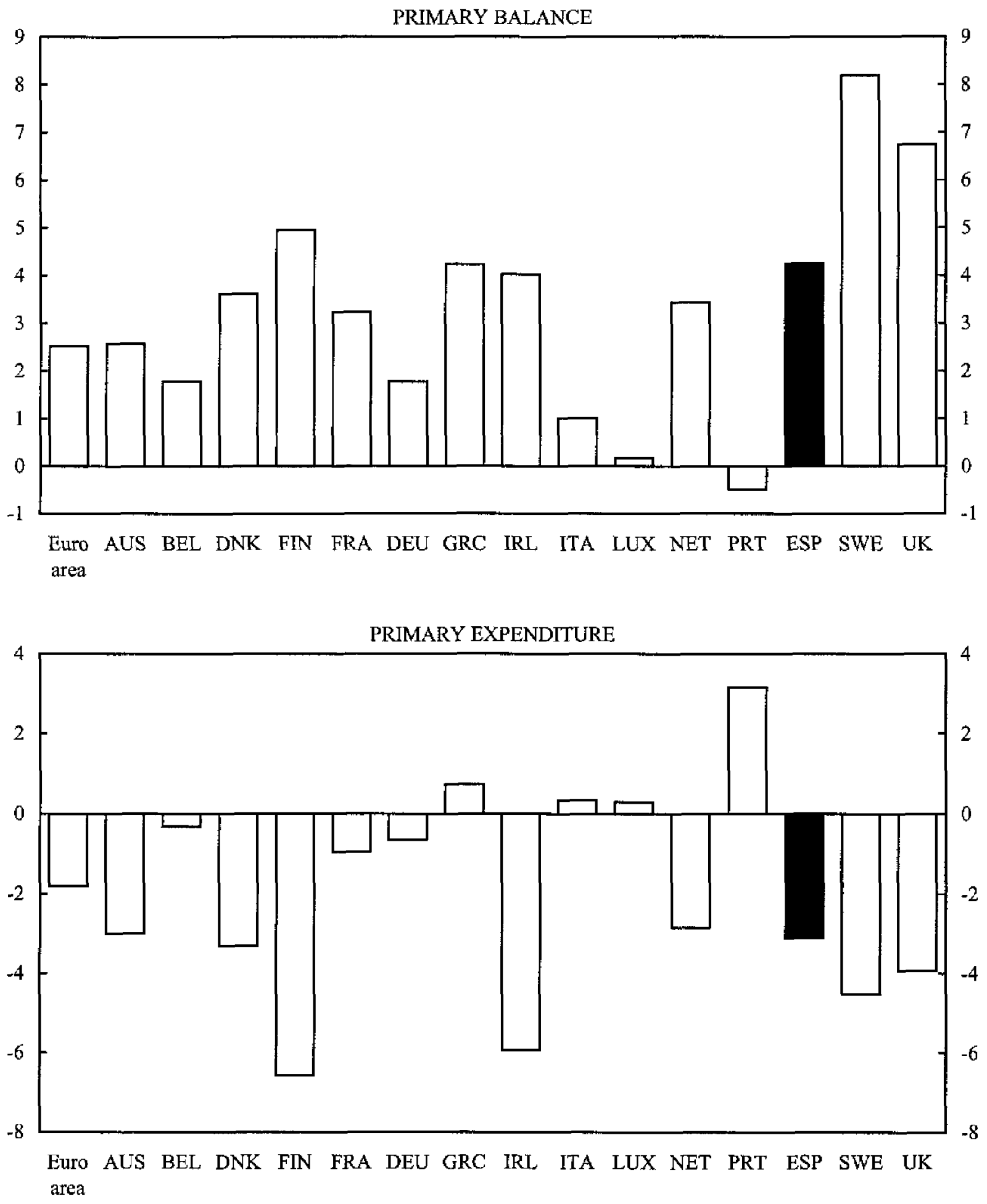

Source: IMF, World Economic Outlook, and Fund staff estimates.

1/ Euro area figures are unweighted averages. 
Figure 8b. Selected Countries: Composition of Fiscal Adjustment, 1995-1999 1/ (Cumulative change, in percent of GDP)
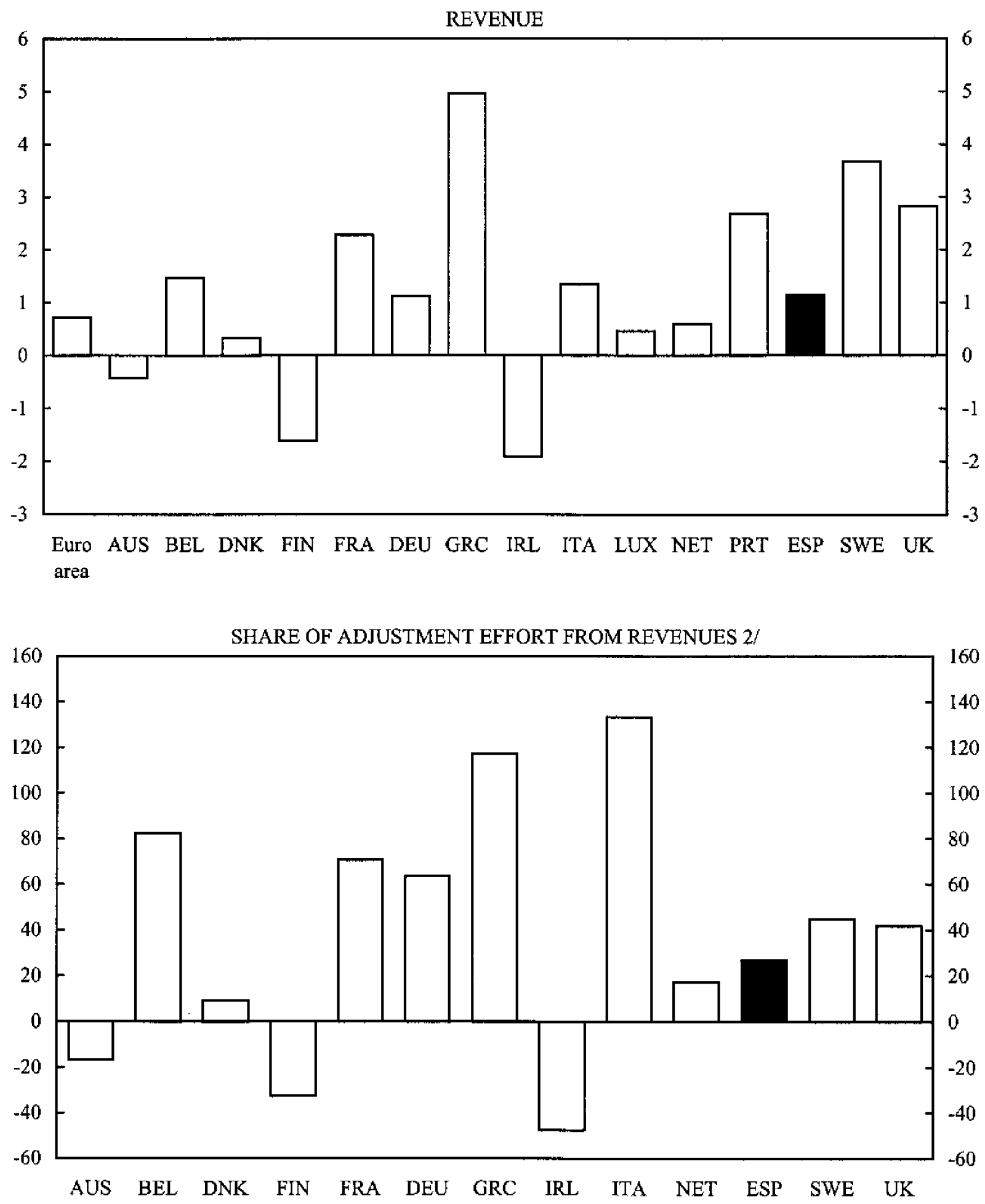

Source: IMF, World Economic Outlook, and Fund staff estimates.

1/ Euro area figures are unweighted averages.

2/ Change in revenues as percentage of change in primary balance. 
would take advantage of favorable economic developments to make rapid progress toward medium-term goals. ${ }^{4}$ While this approach had the important merit of helping to counterbalance relatively accommodative monetary conditions, it should not be interpreted as fiscal fine-tuning. Regarding risks of overheating, any fiscal action to restrain demand, they emphasized, should be buttressed by structural reforms to raise the ceiling for growth. While this approach is essentially consistent with the suggestions made in the staff study of cyclically advanced euro-area economies, the authorities felt the paper put excessive emphasis on the limitations of fiscal policy (Box 1).

- They did not disagree with the staff's assertion that, with continued tight control of expenditure, and if revenues remained buoyant, it could be possible to achieve structural-and not just nominal-balance in 2001. With output above potential by perhaps $3 / 4$ percentage point, structural balance would imply a nominal surplus of $1 / 4$ to $1 / 2$ percent of GDP. In this connection, there was interest in the staff's suggestion that the burgeoning social security surplus should be treated as a downpayment on commitments related to population aging, rather than as an offset to lingering deficits elsewhere in the public sector. This could indeed provide a medium- and longer-term motivation for moving beyond even structural balance to at least a modest structural surplus.

- For the future, nonetheless, the authorities emphasized the need to weigh various competing priorities for fiscal policy. Certainly, a lesson of the past was that fiscal consolidation had boosted confidence, and freed up resources for the private sector. But fiscal policy should be viewed as an instrument of both demand and supply management, including through the removal of bottlenecks arising from infrastructure shortfalls. Though they would continue to involve the private sector in the provision of infrastructure, they planned to increase public investment from the present $31 / 2$ percent of GDP to 4 percent by 2004 (double the euro-area average). It was desirable also to reduce the tax wedge on labor income, though its relatively low level made this less of a priority than for some of Spain's euro-area partners (Figure 9). Continuing consolidation was not without costs, and increasingly large surpluses should not come at the expense of necessary infrastructure investment. ${ }^{5}$ Staff agreed that additional reductions in the tax wedge - while desirableshould not take precedence over further fiscal consolidation.

\footnotetext{
${ }^{4}$ This is in line with the recommendations of the staff report on Monetary and Exchange Rate Policies of the Euro Area.

${ }^{5}$ At the beginning of the 1990 s, Spain had approximately 0.5 kilometer of paved road and 0.04 kilometer of railroad track per square kilometer of area. By contrast, these ratios were 1.4 and 0.06 for France, 1.4 and 0.12 for Germany, and 1.0 and 0.09 for Italy, according to the 1994 World Development Report. Of course, these numbers do not adjust for geography, topology, population density and other factors that may be relevant.
} 


\section{Box 1. Cyclically Advanced Euro-Area Economies: Consequences and Policy Options}

A cross-country paper on policy issues for the cyclically advanced euro-area economies was sent to the Executive Board on July 27 (SM/00/182) in advance of the meeting on Ireland, and provides background information relevant to a number of countries, including Spain.

The paper argues that although overheating within a monetary union will lead to a loss of national competitiveness, the costs associated with this process could be small, especially if it occurs gradually. Costs could be higher, however, if overheating is resolved through a sudden drop in asset prices that provokes problems in financial markets, if tightness in labor markets generates long wage cycles that lead to high unemployment, or if structural rigidities limit the ability to shift production from tradables to nontradables. Problems could be exacerbated if area wide monetary policy becomes restrictive just as the economic cycle enters a downward phase in a cyclically advanced country.

The paper highlights the need for reforms in product and factor markets, as well as continued vigilance by financial sector supervisory authorities, to forestall-_or reduce the potential costs of - overheating. It also makes the case for accelerating progress in fiscal consolidation toward medium-term goals. It notes, however, that the cyclically advanced euro-area countries are primarily small and highly open, reducing the effectiveness of fiscal policy, and recalls traditional concerns about lags in the impact of fiscal policy. As a result, it argues that in cases where the evidence of overheating is compelling, countries will need to opt for discretionary fiscal tightening. However, in most cases, fiscal policy should focus on mediumterm goals such as the achievement of structural balance.

The mission presented a preliminary version of the paper in a seminar with representatives of the Ministry of Economy and the Bank of Spain during the consultation discussions. While agreeing with the general framework of the paper, the authorities expressed two major concerns. First, they believed that the paper was unduly pessimistic about the effectiveness of fiscal policy, even in the small open economies on which, de facto, it concentrated. While a high marginal propensity to import might imply a relatively low fiscal multiplier, the advent of monetary union-by making domestic interest rates exogenous - would prevent "crowding in" from diluting the impact of a fiscal contraction (as in the standard Mundell-Fleming mode1). Moreover, they added that even if fiscal policy were, in general, only modestly effective in small open economies, that did not imply that there do not exist specific, well-targeted fiscal measures that could serve as a brake on aggregate demand even in these countries. They added that the paper focussed exclusively on the demand management aspects of fiscal policy, without considering that fiscal policy can play a role in stimulating the growth of potential output, as well.

Secondly, the authorities felt that while the paper concentrated on how membership in a monetary union could increase the costs of overheating, there are reasons to believe that monetary union could rather act in the opposite direction. They noted that while an overheating country outside of a monetary union will eventually incur an unsustainably large current account deficit, potentially triggering a sudden loss of confidence and contraction, a small country that is a member of a monetary union could in principle run a sizable current account deficit for many years with few repercussions. This increases the likelihood of soft rather than hard landings for overheating economies. In addition, the authorities felt that the tendency for regional economic divergence should be viewed from an historical perspective, noting that regional divergences could narrow in the context of monetary union. First, monetary union had eliminated one major potential source of cyclical divergence by creating a single monetary policy for all members. Second, monetary union had led to a convergence in expectations regarding inflation and other key variables in member countries. 
Figure 9. Selected Countries: Marginal Effective Tax Rates on Additional Family Income, 1998

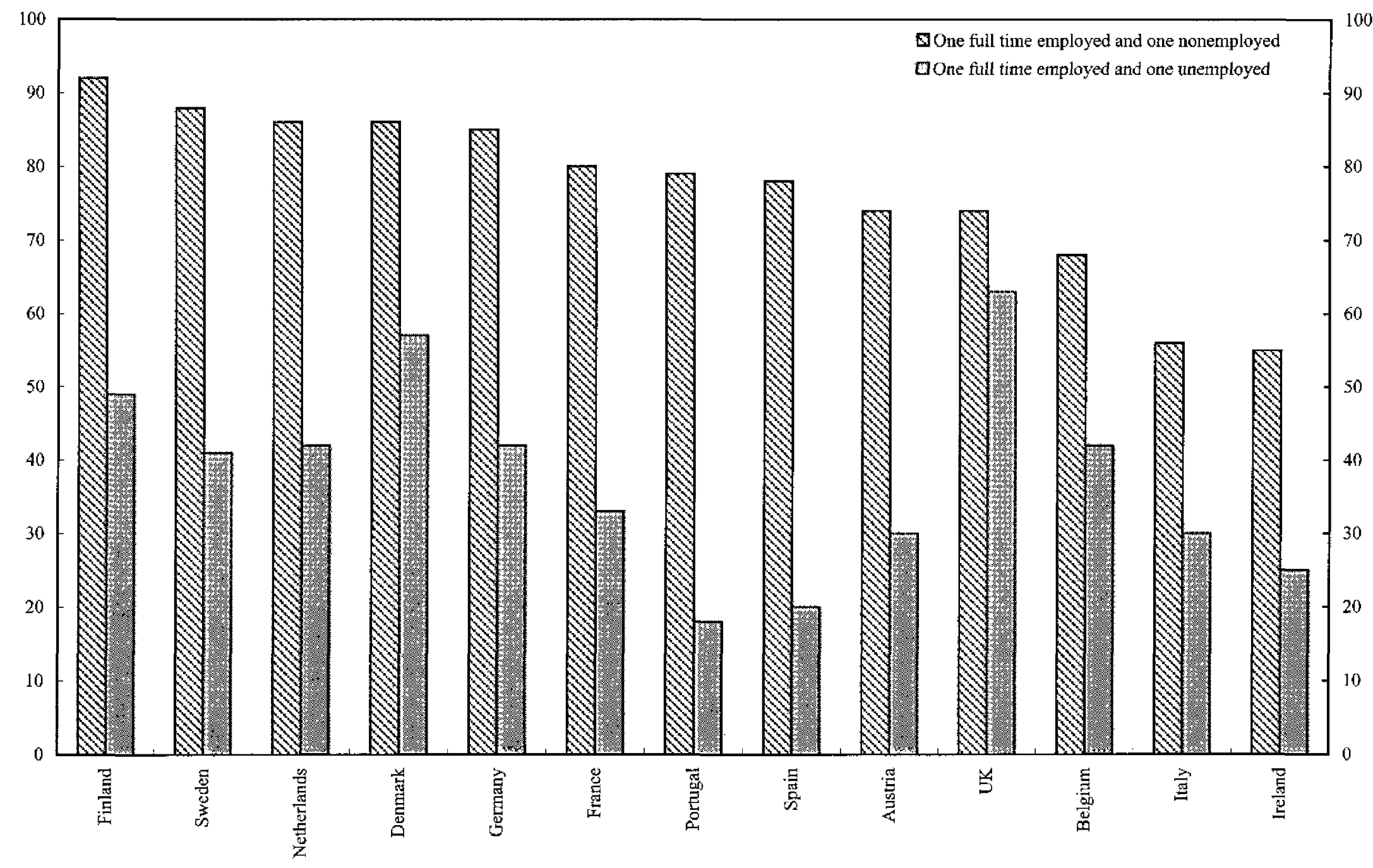

Source: OECD.

Note: The marginal effective tax ratc (METR) is defined as 1 - (change in net income/change in gross income).

Striped bar is the METR for a family with one full-time worker and one adult out of the labor force, while dotted bar is the METR for a family with one full-time worker and one unemployed adult. 
13. The authorities agreed that expenditure control would be enhanced by a fullyfledged multiyear budgeting framework. They indicated that they are in fact considering the introduction of a four-year budget framework (which would be more precise than the broad multiyear outlines established under the Stability Program) under a proposed Budget Stability Law. The staff noted that this should help achieve a strategic reduction in current expenditure: this was the key to ensuring that fiscal consolidation not come at the expense of investment priorities.

14. The authorities categorized experience with the personal income tax reform that came into effect last year as positive, although they noted that final details on its impact were not yet available. The reform reduced marginal tax rates and the number of tax brackets, and replaced numerous tax credits with deductions against pre-tax income. On a preliminary basis, the authorities estimated the revenue loss of the reform as about $3 / 4$ percent of GDP. They are considering an additional personal income tax reform in 2002 or 2003, which would likely involve further reductions in marginal tax rates throughout the income distribution. The mission noted that, if the accounts of the public sector excluding social security were to be balanced, this would imply that any net costs of the proposed reform would need to be offset by equivalent measures to reduce expenditure; greater buoyancy of underlying revenues might increase the scope for cuts in marginal tax rates.

\section{B. Product and Labor Market Reforms}

15. The authorities were convinced of the need to strengthen competition in product markets, launching a package of measures soon after formation of the new government. Their next priority was the labor market, where they stressed the scope to deepen the significant structural reforms achieved through a cooperative approach in recent years. Staff agreed on the critical importance of deepening labor market reforms.

\section{Product market reforms}

16. In June the authorities introduced a package of measures in key sectors, including telecoms, electricity, gas, retail sales, and pharmaceuticals (Box 2). These reforms aimed, inter alia, to reduce the dominance of large firms, especially in network sectors, and to ensure that their competitors had equal access to essential infrastructure. The authorities acknowledged that some of the measures - for example, restrictions on the rights of specific firms to expand their operations - had been criticized in some quarters as interventionist, but noted that direct measures of this kind were essential to address market imperfections. Reforms sought to encourage technological development in SMEs and thus further the growth of the new economy in Spain. Although some of the measures may have a favorable short-term impact on prices, the authorities stated that the package was not intended to be a quick antidote to inflation, but rather to improve efficiency and stimulate aggregate supply in the medium term. Measures related to pharmacies and retail sales provoked very strong reactions among the targeted groups. These measures were, nonetheless, in the view of the staff, essential and quite measured steps in the direction of 


\section{Box 2. The Structural Reform Package of June 23}

On June 23, the authorities introduced a package of structural reform measures that sought to increase competition in key sectors of the economy, encourage investment in new technology by small-and medium-sized firms, and stimulate private saving. Key elements of the package include the following:

- Gasoline companies whose market share is greater than 15 percent will be prohibited from opening new service stations for specified periods (of up to five years). The reform also establishes limits on the ownership shares of refining companies in the Compañta Logística de Hidrocárburos, which controls the market for storage and distribution of gasoline, and seeks to ensure equal access to CLH's infrastructure for all firms.

- The timeframe for complete liberalization of the natural gas sector has been brought forward from 2008 to 2003 , and limits have been established on the maximum stake that any firm may hold in Enagas, which has a monopoly on storage facilities and the distribution pipeline. In addition, a portion of the long-term contract with Algeria for the supply of natural gas-which is now controlled by a single firm-will be opened to other operators.

- Electricity generation companies with market shares greater than 20 percent will be barred from establishing new generating facilities for up to five years. In addition, household electricity tariffs will be reduced by up to 9 percent over the next three years.

- The local telephone network will be opened to competition by January 2001 , and flat rate pricing for local telephone calls will be introduced. In addition, prices for network access will be revised by September 15, and by October 31 a study on ways to promote greater competition in mobile telephony will be produced.

- The reform establishes that municipal governments can only refuse to reclassify land as eligible for urban development for objective reasons, ostensibly eliminating the scope for discretion in these decisions.

- Opening hours for small and medium-sized retail outlets have been completely liberalized (subject to maxima established by regional governments). Maximum weekly opening hours for large stores have been increased from 72 to 90 , and the maximum number of Sundays and holidays these cstablishments are allowed to open will gradually be increased from the current 8 per year to 12 by 2004. Price competition on textbooks has also been authorized.

- Pharmacies will be allowed to offer discounts of up to 10 percent on specified products.

- The reform creates fiscal incentives for small and medium-sized enterprises that assist their employees in acquiring computers for home use, and establishes a flat rate for internet access at offpeak hours. The reform also offers more favorable tax treatment for investment in R\&D.

- To stimulate private saving, the tax rate on long-term capital gains has been reduced from 20 to 18 percent, and the ceiling on tax-favored contributions to private pension funds has been increased. 
more competitive markets. Restrictions remain on opening hours and calendars for large stores, on price competition at the retail level, and on the establishment of new pharmacies, for example. The authorities recognized that scope existed for additional reforms in product markets, highlighting water supply, postal and rail services, and airport administration as possible areas for future reforms.

18. Following an ambitious privatization program, few firms remain in the public sector. Privatization of the last major public sector firm, Iberia Airlines, will be completed via the stock exchange this year. By end-2000, only the public radio and television corporation (RTVE), the railway system (RENFE), and a few defense and mining enterprises will remain in public hands.

19. The authorities saw existing antitrust mechanisms as adequate. Responsibilities are shared among the Servicio de Defensa de la Competencia that is part of the Ministry of Economy, the Tribunal de Defensa de la Competencia, and various specialized regulatory bodies for key sectors such as telecoms and energy. The Tribunal is charged with investigating antitrust complaints, with the Servicio issuing final rulings on proposed mergers, although the Tribunal does have powers to act in other regulatory matters. The authorities saw no conflict of interest arising from having the Servicio within the ministry, noting comparable arrangements in other major countries. They agreed, however, that a review of experience with these regulatory mechanisms might be appropriate in the future, and noted the staff's recommendation to strengthen the resources of the Tribunal.

\section{Labor market reforms}

20. The authorities, unions and employers agreed that the main challenge in the labor market was to promote an expansion of durable employment and an increase in participation. The social and economic costs of Spain's very high unemployment are clear. In addition, the abnormally high ratio of temporary contracts--three times the EU averagesignals continuing distortions in the labor market. While in the view of all parties there are valid roles for temporary employment, in many cases such contracts (often of only a few days' duration) are used on a revolving basis to avoid firing costs. This weakens the incentives for training and skill acquisition, reduces incentives for labor to migrate across regions, and may also help account for Spain's unusually high rate of workforce accidentspoints underlined by the labor unions. A low ratio of part-time work and the very heavy use of temporary contracts, together with wide differences in unemployment rates across regions and a very low participation rate, were cited as distinguishing features of Spain's labor market.

21. The authorities underscored that a cooperative approach to labor market issues had allowed effective reform without provoking work-loss from strikes, and they intended to build on this experience. They, like the unions and employers, considered that the 1997 labor reform had achieved important progress, and an analysis of the reasons for this would be a starting point in designing further measures. A main feature of the 1997 reform was a new permanent contract with lower dismissal costs, and lower social security 
contributions for certain categories of workers. The reform also sought to clarify the definition of "justified dismissals," which carry lower dismissal costs. ${ }^{6}$ Following the reform, the pace of job creation had been very strong: it was also less biased to temporary contracts than in the previous upswing, although the ratio of temporality remained very high (Table 4). Staff agreed on the need to maintain the cooperative approach, but counseled that the search for consensus should not be allowed to unduly delay the implementation of critical reforms.

\section{The authorities, unions, and employers differed somewhat as to the key factors} that had made the 1997 reform effective. Noting that many of the social security subsidy schemes predated the 1997 reform, the authorities tended to stress the effect of cutting dismissal costs. By contrast, unions emphasized the entire package, particularly the improved climate of industrial relations achieved through a cooperative approach. The employers emphasized both lower dismissal costs and social security contribution subsidies, though they noted that the large number of subsidy schemes offered by different levels of government diminished their transparency and effectiveness: they argued for a more general reduction in dismissal costs and social security contributions. One area of broad agreement was the failure of efforts to stimulate part-time jobs, potentially a valuable vehicle for entry into employment, especially for women and the young. (Part-time workers account for only 7 percent of total employment, about half the EU average.) Employers have largely rejected the new permanent, part-time contract as insufficiently flexible, requiring unrealistic advance specification of precise days and hours of work.

\section{In light of recent experience, the authorities thus saw the priorities of a new} round of reforms as fostering more part-time employment; continuing to reduce dismissal costs; increasing the flexibility of the wage bargaining process; and enhancing labor mobility. They also planned to review the effectiveness of rules regarding eligibility for unemployment compensation in encouraging beneficiaries to seek employment or training. In addition, they were considering a program to subsidize social security contributions for a fixed period of time (possibly two years) for women returning to the labor force after maternity leave, to help redress the low level of female participation in the labor market. ${ }^{7}$ Noting that it might not be possible to achieve the same degree of progress on all fronts at once, the authorities highlighted part-time work and a cut in dismissal costs as priorities. Staff agreed with this emphasis, noting that efforts to introduce greater wage

\footnotetext{
${ }^{6}$ Problems with the interpretation of the new definition by labor courts, which had initially fustrated efforts to reduce dismissal costs, have been addressed by a series of recent court decisions.

${ }^{7}$ Contributions for women on maternity leave are already in effect subsidized, as employers are free from making contributions on behalf of workers temporarily hired to replace them. While estimates of the fiscal costs of the new program are not available, the authorities expect them to be relatively modest
} 
flexibility - while highly desirable — would need to come primarily from private sector initiatives.

24. Sizable variations in unemployment rates exist across regions (from 5 percent in the Balearic Islands and Navarra to 25 percent in Andalucia), as well as sexes and ages (unemployment rates among those under 26 and women are, respectively, more than twice those for older individuals and for men). A range of relevant factors were cited in response to the staff questions:

- At a fundamental level, substantial and long-lasting differences in unemployment rates across regions reflect a combination of skill mismatches and insufficient wage variation. As regards skills, the 2000 budget contains a large increase in active labor market policies to improve training for the unemployed, which will begin to address this problem, and there is also a need for more effective cooperation between academic institutions and the social partners to ensure that relevant courses and training are available. Movement on wage differentiation may be harder to achieve. Already, two-thirds of workers covered by collective bargaining agreements are employed under contracts negotiated at the firm, provincial, or regional level, but this does not appear to be resulting in enough flexibility to integrate the young or low-skilled at an adequate pace. There is little correlation between wages and unemployment rates across regions.

- Labor mobility across regions is hampered by a serious shortage of housing, provoked both by municipal financing arrangements that encourage local governments to restrain the supply of land for urban development (discussed further below), and by laws that require rental contracts to be renewable for up to five years at the discretion of the renter.

- The decentralization of employment services may inadvertently have reduced the flow of information about job openings across regions.

- Some areas may still suffer from shortages of critical infrastructure, which the authorities plan to address by continuing to direct public investment to depressed regions.

\section{Medium- and Long-Term Challenges for the Public Finances}

25. The authorities planned to reopen a dialogue with the social partners on steps to further mitigate the impact of population aging on the public finances. They acknowledged that the long-run nature of this problem implied considerable margins of uncertainty in any analysis. And, because the baby boom arrived somewhat late in Spain, serious problems will emerge correspondingly later. But the reforms under the Pacto de Toledo of 1997, while allowing the pension system to generate a cash flow surplus in 1999, 
could not be relied upon to ensure its long-term financial health. ${ }^{8}$ Indeed, some estimates project a doubling of pension expenditures to 20 percent of GDP by mid-century in the absence of reform. ${ }^{9}$ Thus, the authorities plan to begin exploring additional reforms under the five-year review envisioned in the Pacto (due in October 2001).

26. Without prejudice to the results of cooperative discussions, the authorities confirmed that a number of technical measures were under review that would increase the solvency of the pension system and, in some cases, improve incentives by tying benefits more tightly to contributions. Areas for potential consideration could include a partial prefunding of pension obligations (both through transfers from the state budget to the social security system and the accumulation of annual cash flow surpluses), more extensive use of private, firm-based pension plans, and various measures - perhaps including a further increase in the base period for calculating pensions - to effectively reduce the replacement ratio. The authorities also hope to discourage firms from using early retirement schemes to replace older, more highly paid workers with younger, less costly ones at the expense of the social security system. They also wish to encourage workers to remain in the labor force past age 65. In the staff's view, the case for reforms along these lines, in a setting of some uncertainty about the long-run outlook for pension finances, is particularly persuasive given that they would in any case enhance private saving and stimulate labor force participation. The staff seconded the authorities' concerns about reducing early retirement and encouraging older workers to remain in the labor force.

27. A second major structural issue in the public finances is the expiry at end-2001 of the current agreement governing regional and municipal financing (Appendix II). Now that the transfer of expenditure responsibilities to regional governments is largely complete, the authorities hope to reach agreement on a permanent financing arrangement, succeeding carlier five-year agreements. Their goal is to produce a system that is more transparent and also encourages all levels of government to use resources more effectively. Staff noted that the existence of guaranteed revenue transfers means that any decline in tax ratios-whether it results from policy shifts or other factors-falls exclusively on the state budget. Future reforms should address this imbalance.

\section{Regional officials have identified a number of shortcomings with the present} financing system-particularly the practice of transferring to regions a share of the

\footnotetext{
${ }^{8}$ Key measures under the Pacto include relieving the social security system of the financing of health care and noncontributive pensions, widening the pension base to the last 15 years of contributions, and gradually raising the ceiling on contributions. These measures, plus very rapid growth in contributors, resulted in a cash flow surplus of 0.2 percent of GDP in 1999

${ }^{9}$ In addition, staff simulations for last year's Article IV consultation discussions found that population aging and income growth could lead to an increase in health spending from $71 / 2$ percent of GDP now to about 11 percent of GDP by 2050 (see SM/99/138, 6/16/99).
} 
personal income tax collected in their jurisdictions. ${ }^{10}$ Personal income tax collections are subject to considerable variation from year to year, complicating the budgetary process. Regional officials hoped that in the next financing arrangement certain taxes that are administered on a national level (the Impuestos Especiales) would be put under regional control, and that revenue-sharing would be based on the VAT (rather than the personal income tax), with a key based on each region's share of national consumption. They noted that this would provide more stable revenues - consumption varying less than income-and argued that it would also be more progressive, since consumption tax disparities across regions were smaller than income tax disparities. There was also concern that the design of the current system does not result in effective decentralization, as the central government's guarantee that each region's receipts will rise at least as fast as GDP makes the "regional income tax" more closely resemble a transfer.

\section{Both national and regional authorities agreed that financing arrangements for} municipalities had introduced significant distortions in the land market-although this is not a view all municipalities would accept. Municipal governments generate a large portion of their revenues from property, and this encourages them to act as monopoly suppliers, restricting the supply of land for urban development to maximize its price. Through its effects on the cost and availability of housing, labor mobility and job creation are inhibited. ${ }^{11}$ National authorities hoped in the future to mitigate this distortion by diversifying municipalities' income sources, although property-related revenues would doubtless remain important for city governments. As a first step, the June reform package contains a measure limiting the ability of municipal governments to use zoning regulations to restrict urban development (see Box 2).

30. Asked whether fiscal restraint might be weakened with greater decentralization, the authorities considered that continuing firm expenditure control could, with the right arrangements, be favored by decentralization. They recalled the contribution of lower levels of government to Spain's consolidation effort, and the role of the internal stability pact. Controls also existed on short- and long-term market borrowing by regions and municipalities, and their debt levels had stabilized (at about 6 percent of GDP). Also, the proliferation of public enterprises at the regional and municipal levels had ended, in part due to accounting changes that require borrowing by such entities to be consolidated into the public sector accounts. They agreed that it was crucial that incentives embedded in the federal financing arrangements continue to reflect the wide national consensus on fiscal

${ }^{10}$ As part of a series of recent visits to regions, the mission this year traveled to Andalucia to meet with representatives of regional and municipal governments.

11 The ratio of average home value to median family income in Spain is, at 5.3, the third highest in the OECD, trailing only those of Japan (6.6) and the Netherlands (5.5). Of course, this is a function of a variety of factors, including for example details of local mortgage markets, tax treatment of mortgage interest, and population density. 
discipline. Nowhere, the staff suggested, was this truer than for health services, where care should be taken to ensure that decentralization not lead to greater expenditure through the duplication of services. ${ }^{12}$

\section{The Financial Sector}

31. Officials noted that the banking system remains healthy, with high levels of profitability and capital, and the ratio of nonperforming loans at historically low levels. They did not see the recent rapid rate of credit growth as creating undue risks for the banking system, and noted that solvency ratios exceed international standards, while returns on assets and on equity are well above the euro-area average (see Table 5 for additional vulnerability indicators). In addition, earlier in 2000, the Bank of Spain had established a new loan loss provision based on historical loan default rates. This sought to recognize that risk is created when a loan is granted, not when it becomes impaired, and that the expected loss associated with a loan should be evaluated with reference to the entire business cycle and not simply to a particular point in time. Officials underscored that this was a prudential measure with a medium-term orientation; but in the view of the staff it may also be, de facto, a timely signal to the banks in the present cyclical setting. By increasing lending costs, this innovative measure may induce some slowdown in credit growth, although the openness of Spain's financial markets to non-resident competition sets limits to such an effect.

\section{While recognizing that the extensive exposure of Spanish banks in Latin} America posed risks, the authorities felt that adequate measures were in place to insulate the banking system from any downturn in that region. Over the last several years, large Spanish banks have moved forcefully to establish a presence in most of Latin America, and the two largest financial institutions in the region (in terms of assets) are now the Spanish banks BSCH and BBVA. However, the Bank of Spain has required banks to amortize the goodwill associated with these acquisitions rapidly, ensuring a conservative accounting treatment. In addition, it is coordinating supervisory activities with its Latin American counterparts, and has established a special unit within its own supervision department to monitor banks' Latin American activities. Moreover, Spanish banks have retained full control over the management of their subsidiaries; and supervisors noted that both BSCH and BBVA have substantial reserves that would enable them to ride out a significant downturn in the area. They noted also that the business cycles of Europe and Latin America are not synchronized, implying an element of risk diversification.

33. Officials viewed current supervisory arrangements within Spain as satisfactory, and not in need of replacement by unified financial sector supervision nationally (or in the euro area). Responsibilities are currently divided among the Bank of Spain (for commercial and savings banks), the Comisión Nacional del Mercado de Valores (for capital

\footnotetext{
${ }^{12}$ A selected issues paper being prepared for the consultation examines medium-term fiscal challenges.
} 
markets), and the Dirección General de Seguros (for insurance and pensions), with the lead supervisor for financial conglomerates being determined according to each group's principal line of business. While the staff noted that supervisory arrangements such as these-where responsibilities are not coordinated under a single umbrella - have the potential to create coordination problems, the authorities confirmed that this is not the case in Spain. Responsibilities are well-demarcated, and cooperation is enhanced by the fact that the Governor of the Bank of Spain and head of the CNMV are members of each others' boards. The authorities agreed that arrangements would need to continue to respond flexibly over time to keep pace with changes in financial markets, noting staff's suggestion that the expansion of private pensions would likely necessitate additional supervisory resources in the medium term. For a discussion of developments in Spain against the broader background of euro-zone trends and issues, see Box 3.

\section{The authorities reviewed a number of recent measures intended to provide} entrepreneurs and small- and medium-sized firms with greater access to capital. Reforms have made it easier for firms to issue nonvoting and preferred shares; have allowed mutual funds (whose asset base is relatively larger in Spain than in the average EU country) to invest in firms that are not listed on the stock exchange; and have liberalized regulations for venture capital. Most significantly, a new stock market (the Nuevo Mercado) exists, designed to give companies with large profit potential, but high volatility of earnings, access to equity capital. The market is modeled on the U.S. NASDAQ market, with more liberal requirements for market access than in the Madrid Stock Exchange (MSE). High tech firms account for a large portion of market capitalization, which at present is about 20 percent that of the MSE. In addition, a market to trade Latin American shares has been opened, enabling these stocks to be quoted and traded in euros.

\section{Staff APPRAISAL}

35. Spain has seized the opportunities presented by monetary union, and has been rewarded with an enviable economic performance. The private sector has responded strongly to the decisive macroeconomic policy management of recent years, as well as to labor and product market reforms. Complemented by wage moderation, these policies have triggered an unprecedented combination of rapid output and employment growth, with low inflation. Unemployment has declined sharply, and Spanish firms are represented at the forefront of global markets. These successes have won broad recognition for the efforts of the authorities, in cooperation with the social partners.

\section{The challenge now is to press on with reforms that will render growth more} sustainable, bring unemployment down from a still strikingly high level, put fiscal decentralization on a sounder footing, and preempt demographic pressures on spending. In each of these areas, issues remain that, unattended, have the potential to erode Spain's successful economic performance, and the present juncture is an ideal opportunity to further reforms. Inflationary pressures must not weaken competitiveness; uncertainty about long-run developments must not cast a shadow over current fiscal performance; fiscal 


\section{Box 3. Cross-Country Study on Euro-Area Banking}

The European I Department has recently been engaged in a study of banking systems in the euro area, including that of Spain. The staff presented the study in a seminar with representatives from the Ministry of Economy, the treasury, and the Bank of Spain in a seminar during the consultation discussions.

The authorities and staff agreed on four main trends that are rapidly changing the financial landscape in the euro area: (i) the long-term trend toward disintermediation; (ii) an acceleration of consolidation in the financial industry in the wake of Stage 3 of EMU, which thus far has been uneven across countries and has occurred almost exclusively within rather than across national borders; (iii) new technologies, such as internet banking, that are blurring national boundaries and may be used to circumvent traditional barriers to entry in retail banking; and (iv) the rapid growth in euro-area capital markets. To these, the authorities added the issue of links between financial services and telecommunications firms.

The staff study notes that the financial system in the euro area remains bank dominated. Most banking systems remain segmented by country, with few forcign banks having a significant presence in local markets. This is especially true for retail banking. Several ownership structures often exist within the same country, with nonincorporated firms - such as the Spanish cajas de ahorro-playing a prominent role in retail markets. While some banks are highly profitable, euro-area banks are on average less profitable and well capitalized than their U.S. or U.K. counterparts. Spanish banks, however, are a notable exception, with profit ratios and capitalization levels at least equal to those of typical U.S. or U.K. banks. The study also raises the issue of whether existing supervisory arrangements, which are organized along national lines, will prove consistent with the new technological and market landscape.

The authorities welcomed the study and believed it raised important issues. However, they viewed existing supervisory arrangements as appropriate, and in particular, saw no need to create a panEuropean supervisory authority. They also expressed concern that the study could give the impression that nonincorporated firms like the Spanish cajas were lesser players in banking markets. For example, while the study speculated that the presence of the nonincorporated firms could slow or segment technological development in the banking sector, the authorities noted that some Spanish cajas are among the most technologically advanced financial institutions in Europe. More generally, the authorities emphasized that the existence of the cajas has played an important role in enhancing competition in the banking sector. The two largest Spanish commercial banks, BSCH and BBVA, control some 80 percent of the commercial banking market but just 40 percent of the overall banking market. The authorities speculated that without the presence of the cajas these two banks would have assumed a much more dominant position in the overall market. While they recognized that other countries had chosen to incorporate institutions similar to the cajas, they emphasized that this had typically occurred in response to specific problems, a condition which did not apply in Spain. 
devolution needs to preserve expenditure restraint; and structural unemployment has to be reduced.

38. While the short-term outlook is favorable, Spain's rate of inflation is above the euro-area average, which could pose risks in the medium term, particularly if the euro were to appreciate significantly. Monetary conditions in the euro area are unduly easy for the Spanish economy. To forestall risks of overheating, further progress is essential on structural reforms - notably in the labor market - that will increase potential output. In addition, fiscal policy should seize on the strong economic environment to achieve structural balance through additional fiscal withdrawal, moderating any pressures resulting from excess domestic demand. This is desirable in light of Spain's advanced cyclical position, but also for medium- and long-term reasons.

39. In this setting, the decisions to lower the 2000 deficit target to 0.4 percent of GDP, and to accelerate fiscal consolidation relative to Spain's Stability Program, are commendable. Indeed, with continued firm control of expenditure, and if revenues remain buoyant, it appears possible as well as desirable to achieve structural balance in 2001 , which would imply a nominal fiscal surplus about $1 / 4$ to $1 / 2$ percent of GDP, somewhat in excess of the official target. Should demand pressures escalate, the authorities would need to stand ready to tighten fiscal policy further.

40. From a longer run perspective, the first of two major challenges for the public finances is how to address the impact of population aging. Because Spain's demographic shock strikes later than in most advanced economies, its magnitude is particularly hard to gauge. But pension and healthcare spending clearly will rise significantly. In the absence of a sharp rise in labor force participation or heavy immigration, this could lead to a significant increase in the tax wedge. The prudent course is to address these pressures by a combination of fiscal and structural policies that will foster more rapid growth over the medium and long term. From a budgetary perspective, the best immediate step would be to allow the social security system to continue to accumulate a surplus, not using this surplus to offset lingering deficits elsewhere in the public finances - which would imply an overall structural surplus in the coming years. Thus, further-and desirable - efforts to cut taxes should be matched by structural spending reductions, maintaining fiscal consolidation as the primary objective.

Expenditure control would be facilitated by a fully fledged multiyear budgeting framework, to ensure that spending cuts are evaluated strategically and do not fall disproportionately on investment.

41. In addition, it would be prudent to ensure a closer link between pension benefits and contributions, stimulating labor force participation and enhancing the solvency of the pension system. Specifically, possible reform measures include a further lengthening of the reference period for calculating the pensionable base; steps to discourage early retirement and to encourage workers to remain in the labor force after reaching age 65 ; and an increase in the role of private, complementary pension plans. No measures should be taken that would increase incentives or widen eligibility for early retirement. Early action on these reforms in the context of the upcoming renewal of the Pacto de Toledo is warranted. 
42. At least as pressing is the challenge of putting fiscal decentralization on a more permanently sound financial basis. With the transfer of expenditure responsibilities largely complete, the upcoming renegotiation of financing arrangements could usefully widen the revenue base of regional and local governments to reduce variability and eliminate the reliance of local authorities on a few revenue sources, such as property, which has led to serious distortions. Local autonomy - and adequate solidarity to safeguard public services throughout Spain-must be complemented by commitments to protect national fiscal goals and ensure that the burden of future adjustments does not fall disproportionately on any one level of government.

43. With the package of product market measures implemented in June, the authorities have sent a clear signal of commitment to reform. These initiatives should enhance competition in key sectors such as telecommunications, energy, pharmaceuticals and retail sales, and encourage investment in new technologies among small and medium enterprises. Future reforms could more fully liberalize opening hours and calendars and remove remaining restrictions on retail competition. Further measures to enhance competition in key sectors such as electricity may also be needed. Existing regulatory mechanisms have served Spain well, but the financial and human resources of the Tribunal de Defensa de la Competencia could be strengthened.

44. With these strides in product market reform accomplished, the overwhelming priority now lies in further steps to improve the working of Spain's labor market. The authorities' commitment to persevere with a cooperative approach builds on demonstrable success, and at this juncture, indeed, a variety of past approaches need to be deepened. First, experience since the 1997 reform demonstrates that reducing dismissal costs is a key to generating growth of permanent employment contracts. Second, selective cuts in social contributions have a role to play, but the present plethora of schemes reduces transparency. A single program could more effectively be targeted at key groups, and greater coordination with regional and municipal governments could help avoid waste. A further area for action is part-time employment, where earlier efforts need to be strengthened considerably: unions, employers and the government should work together to develop satisfactory revisions to the permanent, part-time contract.

45. Regional disparities in unemployment rates remain troubling. Action is needed to make wage bargaining more responsive to local labor-market conditions, as is more effective training to upgrade the skills of those seeking to enter the jobs market; and it is crucial that incentives encourage those receiving benefits to secure either work or training. Reforms to land taxation and rental housing can address barriers to labor mobility, as can more sharing of information about vacancies: new technologies such as the internet could be harnessed to encourage greater flow of information about local labor markets across regions. Finally, welltargeted infrastructure investment could also help reduce regional unemployment rates:

partnering with private investment can mitigate the strain on the public finances, though care would be needed not to create contingent liabilities. 
46. Regulators have moved judiciously to keep pace with dynamic developments in Spanish financial markets. Existing regulatory mechanisms and coordination, which involve the Bank of Spain, the Comision Nacional del Mercado de Valores, and the Dirección General de Seguros, are functioning well. Of course, regulators will need to continue to respond flexibly as markets evolve. For example, as private pensions increase it will likely prove necessary to dedicate additional resources to their supervision. In banking supervision, the authorities have continued to work to contain any risks arising from the concentration of banks' exposure in Latin America. The conservative accounting treatment of overseas assets along with the new provisioning requirements introduced by the Bank of Spain should provide a margin to allow banks' balance sheets to weather any decline in portfolio quality arising from economic cycles at home or abroad. Notably, these measures were introduced in a climate of intensified supervisory vigilence--including increased coordination with foreign regulators - that will also contribute to containing any risks from high Latin American exposure.

47. Spanish statistical data are adequate for effective surveillance. Statistical authorities have responded ably to changing standards for national accounts, fiscal and other data. Further adaptations will likely be needed in future as international standards continue to evolve.

48. It is proposed that the next consultation be held on the standard 12-month cycle. 
Table 1. Spain: Main Economic Indicators, 1996-2001 1/

\begin{tabular}{|c|c|c|c|c|c|c|}
\hline & \multirow[b]{2}{*}{1996} & \multirow[b]{2}{*}{1997} & \multirow[b]{2}{*}{1998} & \multirow[b]{2}{*}{1999} & \multicolumn{2}{|c|}{ Proj. } \\
\hline & & & & & 2000 & 2001 \\
\hline \multicolumn{7}{|l|}{ Real economy (change in percent) } \\
\hline Real GDP & 24 & 3.9 & 4.3 & 4.0 & 4.1 & 3.5 \\
\hline Domestic demand & 1.9 & 3.4 & 5.6 & 5.5 & 4.5 & 3.4 \\
\hline Private consumption & 2.2 & 3.1 & 4.5 & 4.7 & 4.1 & 3.2 \\
\hline Gross fixed capital formation & 2.1 & 5.0 & 9.7 & 8.9 & 6.9 & 6.0 \\
\hline Exports of goods and services & 10.4 & 15.3 & 8.3 & 6.6 & 9.9 & 11.6 \\
\hline Imports of goods and services & 8.0 & 13.3 & 13.4 & 11.9 & 10.9 & 10.8 \\
\hline CPI (average) & 3.6 & 2.0 & 1.8 & 2.3 & 3.2 & 2.4 \\
\hline Unemployment rate (in percent) & 22.2 & 20.8 & 18.8 & 15.9 & 14.0 & 12.6 \\
\hline Gross national saving (percent of GDP) & 21.9 & 22.6 & 23.0 & 22.5 & 23.4 & 24.5 \\
\hline Gross domestic investment (percent of GDP) & 21.9 & 22.2 & 23.2 & 24.7 & 26.4 & 27.1 \\
\hline \multicolumn{7}{|l|}{ Public finance (percent of GDP) } \\
\hline Central government balance & -4.3 & -2.9 & -2.3 & -0.9 & -0.3 & 0.0 \\
\hline General government balance & -4.9 & -3.2 & -2.6 & -1.1 & -0.4 & 0.0 \\
\hline Structural balance & -3.2 & -1.9 & -1.9 & -1.1 & -0.9 & -0.5 \\
\hline General government debt & 67.2 & 65.8 & 64.8 & 63.5 & 62.8 & 60.6 \\
\hline \multicolumn{7}{|l|}{ Money and credit (end of year, percentage change) } \\
\hline Credit to households and firms & 5.8 & 11.9 & 16.2 & 17.3 & $\ldots$ & $\ldots$ \\
\hline Broad money ( $A \perp P)$ & 7.4 & 4.3 & 1.0 & $\ldots$ & $\ldots$ & $\ldots$ \\
\hline \multicolumn{7}{|l|}{ Interest rates (percent) } \\
\hline Money market rate & 7.5 & 5.4 & 4.2 & 2.9 & $\ldots$ & $\ldots$ \\
\hline Govemment bond yield & 8.7 & 6.4 & 4.8 & 4.7 & $\ldots$ & $\ldots$ \\
\hline \multicolumn{7}{|l|}{ Balance of payments (percent of GDP) } \\
\hline Trade balance & -2.6 & -2.3 & -3.2 & -4.9 & -6.2 & -6.5 \\
\hline Current account balance & 0.0 & 0.4 & -0.2 & -2.1 & -2.9 & -2.6 \\
\hline Official reserves excl. gold (USS billions) & 57.9 & 68.4 & 55.3 & 32.6 & $\ldots$ & $\ldots$ \\
\hline Reserve cover (months of imports) & 4.8 & 5.8 & 4.2 & 2.7 & $\ldots$ & $\ldots$ \\
\hline \multicolumn{7}{|l|}{ Exchange rate } \\
\hline Exchange rate regime & & & Meml & EMU & & \\
\hline Euros per U.S. dollar (August 30, 2000) & & & & & 1.12 & \\
\hline Nominal effective rate $(1990=100)$ & 80.9 & 77.2 & 76.9 & 75.6 & $\ldots$ & $\ldots$ \\
\hline Real effective rate $(1990=100)$ & 89.2 & 85.2 & 85.2 & 84.8 & $\ldots$ & $\ldots$ \\
\hline
\end{tabular}

1/Figures for 2000-01 are Fund staff projections. 
Table 2. Spain: Medium-Term Fiscal Scenario on Present Policies, 1996-2003 $\underline{1}$

\begin{tabular}{|c|c|c|c|c|c|c|c|c|}
\hline & \multicolumn{8}{|c|}{ Proj. } \\
\hline & 1996 & 1997 & 1998 & 1999 & 2000 & 2001 & 2002 & 2003 \\
\hline & \multicolumn{8}{|c|}{ (In percent of GDP) } \\
\hline Total revenues & 39.2 & 39.4 & 39.5 & 40.0 & 40.1 & 40,0 & 39,9 & 39.9 \\
\hline Indirect taxes & 10.2 & 10.5 & 11.1 & 11.7 & 12.1 & 12.1 & 12.1 & 12.2 \\
\hline Direct taxes & 10.3 & 10.5 & 10.2 & 10.3 & 10.3 & 10.1 & 10.1 & 10.0 \\
\hline Social security contributions & 13.2 & 13.1 & 13.1 & 13.1 & 13.0 & 12.9 & 12.9 & 12.8 \\
\hline Other revenues & 5.6 & 5.3 & 5.1 & 5.0 & 4.8 & 4.8 & 4.8 & 4.8 \\
\hline Current expenditures & 39.0 & 37.6 & 37,0 & 35.8 & 35.2 & 34.5 & 34.0 & 33.7 \\
\hline Public consumption & 17.9 & 17.6 & 17.5 & 17.3 & 16.8 & 16.4 & 16.1 & 16,0 \\
\hline Current transfers & 13.8 & 13.3 & 12.8 & 12.4 & 12.3 & 12.1 & 12.0 & 12.0 \\
\hline Itterest payments & 5.3 & 4.8 & 4.3 & 3.6 & 3.6 & 3.5 & 3.3 & 3.3 \\
\hline Other current expenditures & 2.0 & 2.0 & 24 & 2.5 & 2.5 & 2.5 & 2.5 & 2.5 \\
\hline Current balance & 0.2 & 1.8 & 26 & 4.2 & 5.0 & 5.5 & 5.9 & 6.2 \\
\hline Gross fixed capital formation & 3.2 & 3.2 & 3,4 & 3.4 & 3.4 & 3.6 & 3.7 & 3.7 \\
\hline Capital transfers and other & 2.0 & 1.8 & 1.8 & 1.9 & 2.0 & 2.0 & 1.9 & 1.9 \\
\hline Primary balance & 0.4 & 1.6 & 1.7 & 2.5 & 3.1 & 3.5 & 3.7 & 3.8 \\
\hline Overall balance & -4.9 & -3.2 & -2.6 & -1.1 & -0.4 & 0.0 & 0.4 & 0.6 \\
\hline State & -3.9 & -2.7 & -2.1 & -1.1 & -0.6 & -0.3 & 0.0 & 0.1 \\
\hline Territorial governments & -0.6 & -0.3 & -0.3 & -0.2 & -0.1 & 0.0 & 0.0 & 0.0 \\
\hline Social security & $-0,4$ & -0.2 & -0.1 & 0.2 & 0.3 & 0.3 & 0.4 & 0.5 \\
\hline Government debt & 68.1 & 66.7 & 64.6 & 63.3 & 62.8 & 60.6 & 58.1 & 55.8 \\
\hline \multicolumn{9}{|l|}{ Mernorandum iferns: } \\
\hline Structural primary balance $2 /$ & 1.8 & 2.6 & 2.0 & 2.3 & 2.4 & 2.9 & 3.2 & 3.4 \\
\hline Structural balance $2 /$ & -3.2 & -1.9 & -1.9 & -1.1 & -0.9 & -0.5 & 0.0 & 0.2 \\
\hline Struetural expenditure & 42.6 & 41.5 & $4 \mathrm{I} .4$ & 40.8 & 40.9 & 40.4 & 39.9 & 39.6 \\
\hline Structural revenue & 39.5 & 39.6 & 39.4 & 39.8 & 40.0 & 39.9 & 39.9 & 39.9 \\
\hline Output gap & 2.4 & 1.7 & 0.7 & 0.0 & -0.7 & -0.8 & -0.6 & -0.5 \\
\hline
\end{tabular}

Sources: Cuentas Financieras, Bank of Spain; Intervencion General de la Administracion del Estodo; and Fund staff projections.

W/ Scenario assurnes revenues for 2001-03 consistent with the Stability Program, expenditure euts as needed to achicve fiscal balance in 2001, and changes in the overall balance in 2002 and 2003 identical to those in the Stability Program.

2/ Potential output and output gap from staff. For 2000, excludes 0.1 percent of GDP received from the awarding of mobile telephone licenses. 
Table 3. Spain: Authorities' Stability Plan, 2000-03

\begin{tabular}{|c|c|c|c|c|c|c|}
\hline & \multirow[b]{2}{*}{1998} & \multirow[b]{2}{*}{1999} & \multicolumn{4}{|c|}{ Plan } \\
\hline & & & 2000 & 2001 & 2002 & 2003 \\
\hline \multicolumn{7}{|l|}{ General government 1 / } \\
\hline Revenue & 39.9 & 40.1 & 40.1 & 40.0 & 39.9 & 39.8 \\
\hline Expenditure & 42.2 & 41.3 & 40.8 & 40.4 & 39.8 & 39.5 \\
\hline Current expenditure & 37.1 & 36.1 & 35.5 & 35.0 & 34.3 & 33.9 \\
\hline Of which: intercst payments & 4.4 & 3.8 & 3.6 & 3.6 & 3.5 & 3.4 \\
\hline Capilal expenditure & 5.1 & 5.2 & 5.3 & 5.4 & 5.5 & 5.6 \\
\hline \multicolumn{7}{|l|}{ Of which: gross fixed capital } \\
\hline formation & 3.3 & 3.4 & 3.5 & 3.6 & 3.7 & 3.8 \\
\hline Balance & -2.3 & -1.3 & -0.8 & -0.4 & 0.1 & 0.2 \\
\hline State & -1.8 & -1.1 & -0.8 & -0.5 & 0.0 & 0.0 \\
\hline Social security & -0.2 & 0.0 & 0.1 & 0.1 & 0.1 & 0.2 \\
\hline Territorial governments & -0.3 & -0.2 & -0.1 & 0.0 & 0.0 & 0.0 \\
\hline Gross debt & 64.8 & 63.5 & 62.8 & 60.6 & 58.1 & 55.8 \\
\hline Primary balance & 2.1 & 2.6 & 2.9 & 3.2 & 3.6 & 3.6 \\
\hline \multicolumn{7}{|l|}{ Macroeconomic scenario $2 /$} \\
\hline Real GDP & 4.0 & 3.7 & 3.7 & 3.3 & 3.3 & 3.3 \\
\hline Private consumption & 4.1 & 4.4 & 3.7 & 2.7 & 2.7 & 2.7 \\
\hline Public consumption & 2.0 & 1.3 & 1.2 & 1.2 & 1.2 & 1.2 \\
\hline Gross fixed capital formation & 9.2 & 9.2 & 9.2 & 6.9 & 6.9 & 6.9 \\
\hline Domestic demand & 5.0 & 5.0 & 4.6 & 3.6 & 3.6 & 3.6 \\
\hline Exports & 7.1 & 6.9 & 9.3 & 9.8 & 9.8 & 9.8 \\
\hline Imports & 11.1 & 11.7 & 11.9 & 10.1 & 10.1 & 10.1 \\
\hline \multicolumn{7}{|l|}{ Other variables } \\
\hline GDP deflator & 2.3 & 2.6 & 2.0 & 2.0 & 2.0 & 2,0 \\
\hline Private consumption deflator & 2.0 & 2.3 & 2.0 & 1.9 & 1.9 & 1.9 \\
\hline Employment & 3.7 & 3.2 & 2.7 & 2.2 & 2.2 & 2.2 \\
\hline \multicolumn{7}{|l|}{ Authorities' low-growth scenario } \\
\hline Real GDP growth $2 /$ & 4.0 & 3.7 & 3.5 & 3.0 & 3.0 & 3.0 \\
\hline General government balance & -2.3 & -1.3 & -0.8 & -0.5 & 0.0 & 0.0 \\
\hline Gross debt & 64.8 & 63.5 & 62.9 & 60.9 & 58.9 & 57.1 \\
\hline
\end{tabular}

Source: Spanish authorities; presented in late 1999.

1/ On an ESA95 basis.

2/ The authorities' plan provides only average percent changes over 2001-03. 
Table 4. Spain: Sources of Employment Growth, 1997-2000 1/

(In percent)

\section{By sector:}

Share of stock of employment in 1997

Share of employment growth, 1997-2000 2/

By length of work week:

Share of stock of employment in 1997 3/

Share of employment growth, 1997-2000 2/

\section{By length of contract:}

Share of stock of employment in $19973 /$

Share of employment growth, 1997-2000 2/
Total

100.0

100.0

Agriculture
9.0

9.0
-7.5

\section{Total}

100.0

100.0

Full-time
92.1
89.5

Industry Construction

19.9

19.9

19.7

9.7

19.7
Services Public Sector
$43.6 \quad 17.9$
$52.4 \quad 15.6$

Sourcc: Bank of Spain, Statistical Bulletin.

1/ Figures are for first quarter of 1997 and first quarter of 2000.

2/ Change in employment for each category between 1997 and 2000 as a percentage of change in total employment.

3/ Data refer to salaried workers only. 
Table 5. Spain: Indicators of External and Financial Vulnerability 1/

(In percent of GDP, unless otherwise indicated)

1995 1996 1997

1998

1999

$\frac{2000}{\text { Latest } \begin{array}{r}\text { Date of } \\ \text { observation }\end{array} \text { observation }}$

Externat indicators 1

Exports (annual percent change, in U.S. dollars)

Imports (annual percent change, in U.S. dollars)

Terms of trade (annual percent change)

Current account balance (settlements basis)

Capital and financial account balance

Of which: Inward portfolio investment. (debt securities etc.)

Inward foreign direct investment

Other investment liabilities (net)

Official reserves (in billions of U.S. dollars, end of period) 2

Broad money to reserves

Central bank foreign liabilities (in billions of U.S. dollars, ) $2 /$

Foreign assets of the financial sector (in billions of U.S. dollars)

Foreign liabilities of the financial sector (in billions of U.S. dollats)

Official reserves in months of imports 2

Total extemal debt

of which: General government debt

Total extemal debt to exports (ratio)

Exchange rate (per U.S. dollars, period average)

$\begin{array}{rrr}25.0 & 12.3 & 2.1 \\ 23.2 & 7.7 & 0.7 \\ -1.3 & 2.0 & 0.7 \\ 0.0 & 0.0 & 0.4 \\ 0.8 & 0.4 & 0.6 \\ 3.6 & 0.5 & 2.3 \\ 1.1 & 1.1 & 1.1 \\ -5.2 & 3.3 & 3.3 \\ 34.5 & 57.9 & 68.4 \\ 16.4 & 10.1 & 7.7 \\ 0.8 & 1.2 & 0.6 \\ 147.0 & 140.0 & 121.5 \\ 112.1 & 133.6 & 144.8 \\ 3.7 & 4.8 & 5.8 \\ 20.8 & 21.1 & 23.1 \\ 14.1 & 14.0 & 15.7 \\ 1.3 & 1.3 & 1.2 \\ 124.7 & 126.7 & 146.4\end{array}$

4.6
8.2
-0.3
-0.2
1.1
2.9
2.0
3.9
55.3
9.5
0.1
127.1
177.0
4.2
24.5
16.2
1.3
149.4

1.0
9.0
-0.9
-2.1
3.2
7.8
1.6
2.7
33.0
10.1
4.7
129.9
198.3
2.7
30.6
18.2
1.7
156.2

\section{9}

$-6.2$

$-2.7$

3.7

5.0

4.7

August

\section{Financial market indicators}

Public sector debt (Maastricht definition)

12-month T-bill yield

$\begin{array}{rr}63.9 & 68.1 \\ 9.8 & 7.2 \\ 6.2 & 5.2 \\ 100.0 & 124.0 \\ 100.0 & 121.4 \\ 5.4 & 3.9\end{array}$

66.7
5.0
3.2
187.8
207.2
1.7

64.6
3.8
1.5
276.1
336.3
0.4

63.3
3.0
0.4
302.0
355.1
0.1

$\cdots$

$\begin{array}{rr}5.0 & \text { September } \\ 1.5 & \text { August } \\ 329.9 & \text { July } \\ 413.1 & \text { July } \\ 0.1 & \text { August }\end{array}$

\section{Financial sector risk indicators}

Share of foreign exchange loans in total lending (percent)

Share of foreign deposits in total deposits (percent)

Share of real estate sector in private credit

Share of nonperforming Joans in total loans

Share of nonperforming loans in total assets

Risk-based capital asset ratio

$\begin{array}{rrrrr}7.7 & 8.4 & 9.9 & 10.5 & \ldots \\ 5.5 & 5.4 & 6.1 & 7.7 & \ldots \\ 24.0 & 25.5 & 27.4 & 27.8 & 28.7 \\ 5.2 & 3.9 & 2.5 & 1.7 & 1.2 \\ 2.2 & 1.7 & 1.1 & 0.8 & 0.6 \\ \ldots & \ldots & 12.2 & 11.5 & 11.1\end{array}$

Sources: Bark of Spain, Economic Bulletin and Statistical Bulletin; data provided by the authorities; and IMF, International Financial Statistics.

$1 /$ The interpretation of some indicators is affected by the launch of monetary union in 1999.

2/ Reserves and foreign liabilities refer to the Bank of Spain, both belore and after EMU. 


\section{What Explains Spain's Low Productivity Growth?}

Apparent labor productivity growth in Spain has declined sharply in recent years, and by some measures was even negative in 1999 and the first quarter of 2000. If correct, this would imply that despite continued wage moderation unit labor costs in Spain are rising and exporters are gradually losing competitiveness, at least relative to other members of the common currency area. It would also limit Spain's ability to raise per capita income over the medium-term, although per capita income could rise for some time simply through further decreases in the unemployment rate and increases in the participation rate. Data on employment growth from two different official series - the quarterly labor force survey (EPA) and the national accounts employment series - on real output growth, and the resulting productivity growth rates for $1997-2000$ are presented in the table below. ${ }^{1}$

\begin{tabular}{lcccc}
\hline \multirow{4}{*}{ Spain: Output, Employment and Productivity Growth, $1997-2000$} \\
\cline { 2 - 5 } & \multicolumn{5}{c}{1997} & 1998 & 1999 & 2000 Q1 \\
\cline { 2 - 5 } Real output growth & 3.9 & 4.3 & 4.0 & 4.2 \\
EPA employment growth & 3.0 & 3.4 & 4.6 & 4.7 \\
National accounts cmployment growth & 3.2 & 3.8 & 3.6 & 3.3 \\
Productivity growth EPA & 0.9 & 0.9 & -0.6 & -0.5 \\
Productivity growth national accounts & 0.7 & 0.5 & 0.4 & 0.9 \\
Productivity growth in euro-area & 1.6 & 1.0 & 0.7 & $\ldots$ \\
\hline
\end{tabular}

Sources: Spanish authorities; and Fund staff calculations.

Explanations for the low-and possibly even negative-apparent productivity growth in Spain fall into two categories: those that start from the premise that productivity growth really is low and attempt to account for this fact; and those that argue that productivity figures are distorted by problems with the output and employment series. Of course, the two categories are not mutually exclusive.

Within the first category, much of the employment growth in recent years has occurred in fields such as construction and tourism where productivity levels are relatively low. This shift in the mix of employment results in an apparent reduction in labor productivity for the economy as a whole, even though productivity growth within each sector is unchanged. In addition, many of the workers filling these new jobs may be new entrants to the labor force or relatively long-term unemployed, with lower skill levels than their coworkers. Moreover, very rapid employment growth may have resulted in a temporary decline in the capital-labor ratio (despite high investment in recent years), which will imply a short-term decline in labor productivity. Finally, a recent Bank of Spain study finds that a failure to account for the

\footnotetext{
${ }^{1}$ The figure for EPA employment growth in 2000 eliminates statistical effects arising from changes in the employment survey sample.
} 
presence of market power among Spanish firms will for technical reasons downwardly bias estimates of total factor productivity obtained assuming perfect competition. ${ }^{2}$

Within the second category of explanations, observers have suggested that much of the recorded growth in employment (and hence decline in the unemployment rate) really reflects movement of workers from the underground economy into the formal labor market, prompted in part by recent labor market reforms. The very rapid growth of registrations with the social security administration in recent years gives some credibility to this claim. In addition, output growth may be understated in the national accounts data, which would also depress recorded productivity growth. The fact that receipts from the value added tax rose more than twice as quickly as consumption in 1999 suggests this factor may also be at work.

Overall, it would seem that Spain's low apparent productivity growth results from a combination of the above factors. Fortunately, the explanations discussed above all imply that the impact on unit labor costs and competitiveness is either zero (employment mix, statistical problems) or short-term (low initial human capital, declining capital/labor ratio).

${ }^{2}$ See Georges Siotis, "Market Power, Total Factor Productivity (TFP) Growth, and Structural Change: an illustration for Spain, 1983-96," Bank of Spain Working Paper No. 2001. In the presence of imperfect competition, factor shares will generally not be equal to their output elasticities, which will bias estimates of TFP obtained as the residual from a standard growth accounting framework. 


\section{Fiscal Decentralization in Spain}

Of the 17 regions in Spain, 15 are covered by the so-called "Common Regime" for sharing revenues (see SM/97/76 3/5/97 for details). Under this regime, regional governments have access to the following revenue sources:

- taxes on wealth, inheritances, property transactions, legal acts and gambling (the "ceded taxes");

- user charges and fees for services;

- a 30 percent share of personal income tax revenues collected in their jurisdictions;

and

- a share of overall tax revenues collected by the central government (the Participacion en los Ingresos del Estado, or PIE).

The PIE for each region was initially calculated to ensure that each had sufficient resources (given the other revenue items) to provide a minimum level of services to its population. The PIE was renegotiated every five years, but between years would rise or fall in direct proportion with central government revenues. In 1997 the rules governing the PIE were altered, so that from now on the PIE will rise in line with national GDP rather than with national tax revenues, and will not be subject to renegotiation every five years. At the same time, regions were given the right to vary (within limits) the rates and deductions on the personal income tax in their jurisdictions, although to date no region has chosen to modify marginal tax rates. In addition, a guarantee scheme was introduced under which the central government would ensure that each region's revenues from its share of the personal income tax will rise at least as fast as national GDP. Of the 15 common regime regions, three (Andalucia, Castilla la Mancha and Extremadura) refused to accept the innovations of the 1997 financing arrangement. These three regions continue to receive their PIE based on the old formula (with no guarantee that it will grow in line with GDP), although without the provision for recalculation on a five-yearly basis. In addition, these regions do not have the right to vary the tax rate on the personal income tax or to collect the ceded taxes, as both rights were introduced as elements of the 1997-2001 financing arrangements.

The two regions not covered by the Common Regime are the Basque Country and Navarra. For historical reasons, these regions have their own personal and corporate income taxes, and collect most tax revenues independently of the central government. Most expenditure responsibilities have also been devolved to these regions. The two regions provide an annual payment to the national government to cover their shares of expenses that are borne by the national government - such as defense and foreign affairs - with the share determined by the ratio of regional to national GDP.

Expenditure responsibilities devolved to common regime regions are less extensive, but have grown relatively rapidly, and regional governments now account for about one-fourth of total public sector spending, compared to less than 5 percent in the early $1980 \mathrm{~s}$. Among the most important categories of expenditure transferred to the regions are social services, active labor 
market policies, and some infrastructure investments. Responsibility for health care and primary and secondary education has been transferred to a number of regions, and all regions will eventually be responsible for these expenditures.

Borrowing by the regions is subject to various legal constraints: approval of the central government is required for all bond issues and foreign currency borrowing, even though these obligations carry no central government guarantee; short-term borrowing can be undertaken only for purposes of liquidity management; long-term debt can be issued only to finance investment expenditure; and debt service cannot be higher than 25 percent of a region's current revenues. The requirement that the central government approve bond issues of regional governments raises the possibility that a region that failed to achieve its deficit targets under the internal stability pact could face financing constraints. 


\section{Spain: Fund Relations}

(As of August 31, 2000)

I. Membership Status: Spain became a member of the Fund on September 15, 1958. On July 15, 1986, Spain accepted the obligations of Article VIII, Sections 2, 3, and 4 of the Articles of Agreement.

II. General Resources Account:

Quota

Fund holdings of currency

Reserve position in Fund

Operational budget transfers (net)

III. SDR Department:

Net cumulative allocation Holdings
SDR Million

$3,048,90$

$2,131.77$

917.14

$-17.00$

SDR Million

298.81

214.44
$\%$ Quota

100.0

69.9

30.1

$\%$ Allocation

100.0

71.8

IV. Outstanding Purchases and Loans: None

V. Financial Arrangements:

Type

Stand-by

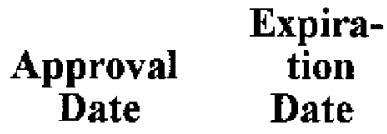

$2 / 06 / 78$

$2 / 05 / 79$
Amount

Approved

(SDR Million)

143.19
Amount

Drawn

(SDR Million)

0.0

VI. Projected Obligations to Fund: None

VII. Exchange Rate Arrangement:

Spain entered the final stage of European Economic and Monetary Union on January 1, 1999 , at a rate of 166.386 Spanish pesetas per euro. Under the arrangement, internal exchange rates with respect to the national currencies of EMU participants were fixed to the euro on January 1, 1999, whereas the external exchange rate of the euro is market-determined.

\section{Article IV Consultations:}

The last Article IV consultation was concluded on June 30, 1999. Spain is on the standard 12-month consultation cycle. 


\section{Spain: Statistical Issues}

Spain's economic data on the core variables needed for surveillance are at acceptable standards of quality, coverage and timeliness. The authorities are fully cooperative in providing data to the Fund, and do so regularly. The Bank of Spain and the Ministry of Economy transmit data electronically to the Fund on a monthly basis, and a wide variety of data and documents are available from Internet sites maintained by the National Statistics Institute, the Bank of Spain, the Ministry of Economy, and other official agencies. Spain has subscribed to the Special Data Dissemination Standards.

Data on the budgetary balance of the general government on both a cash and accruals basis are available, but greater information about the calculations involved in reconciling the two deficit measures would increase the transparency of government accounts. In addition, data on budgets and fiscal outturns for regional governments are available only on an aggregate basis. Two different measures of unemployment are reported by the authorities (so-called "registered" and "survey" unemployment), which vary substantially. A wider dissemination of the methodological differences in calculating these numbers would aid in their interpretation. Data on employment growth are distorted by the flow of workers from the informal to the formal labor force, which complicates the calculation of productivity growth and hence unit labor costs. The very large growth in receipts from the value added tax in 1999 may indicate that consumption and output growth are being underreported in the national accounts data. National accounts and fiscal data through 1995 have been revised in line with the 1995 version of the European System of Accounts, but pre-1995 data have yet to be revised. 
Spain: Core Statistical Indicators

(As of September 26, 2000)

\begin{tabular}{|c|c|c|c|c|c|c|c|c|c|c|c|}
\hline & $\begin{array}{l}\text { Exchange } \\
\text { Rates }\end{array}$ & $\begin{array}{c}\text { International } \\
\text { Reserves }\end{array}$ & $\begin{array}{l}\text { Central } \\
\text { Bank } \\
\text { Balance } \\
\text { Sheet }\end{array}$ & $\begin{array}{l}\text { Broad } \\
\text { Money }\end{array}$ & $\begin{array}{l}\text { Interest } \\
\text { Rates }\end{array}$ & $\begin{array}{l}\text { Consumer } \\
\text { Price } \\
\text { Index }\end{array}$ & $\begin{array}{l}\text { Exports/ } \\
\text { Imports }\end{array}$ & $\begin{array}{l}\text { Current } \\
\text { Account } \\
\text { Balance }\end{array}$ & $\begin{array}{c}\text { Overall } \\
\text { Government } \\
\text { Balance 1f }\end{array}$ & GDP/GNP & $\begin{array}{l}\text { External } \\
\text { Debt } 2 /\end{array}$ \\
\hline $\begin{array}{l}\text { Date of Latest } \\
\text { Observation }\end{array}$ & $9 / 26 / 00$ & $8 / 30 / 00$ & $7 / 30 / 00$ & $7 / 30 / 00$ & $9 / 26 / 00$ & $8 / 00$ & $6 / 00$ & $6 / 00$ & 1999 & 0002 & $00 Q 1$ \\
\hline Date Received & $9 / 26 / 00$ & $9 / 7 / 00$ & $9 / 21 / 00$ & $8 / 31 / 00$ & $9 / 26 / 00$ & $9 / 14 / 00$ & $9 / 14 / 00$ & $9 / 14 / 00$ & $3 / 16 / 00$ & $9 / 20 / 00$ & $8 / 30 / 00$ \\
\hline Frequency of Data & Daily & Monthly & Monthly & Monthly & Daily & Monthly & Monthly & Monthly & Annual & Quarterly & Quarterly \\
\hline Frequency of & Daily & Monthly & Monthly & Monthly & Daily & Monthly & Monthly & Monthly & Annual & Quarterly & Quarterly \\
\hline Source of Update & Reuters & $\begin{array}{l}\text { Central bank; } \\
\text { Reuters }\end{array}$ & Central bank & $\begin{array}{l}\text { Central bank; } \\
\text { Reuters }\end{array}$ & $\begin{array}{l}\text { Central bank; } \\
\text { Reuters }\end{array}$ & $\begin{array}{l}\text { National } \\
\text { Institute of } \\
\text { Statistics; } \\
\text { Reuters }\end{array}$ & $\begin{array}{l}\text { Central bank; } \\
\text { Reuters }\end{array}$ & $\begin{array}{l}\text { Central bank; } \\
\text { Reuters }\end{array}$ & $\begin{array}{l}\text { Ministry of } \\
\text { Finance }\end{array}$ & $\begin{array}{l}\text { National } \\
\text { Institute of } \\
\text { Statistics; } \\
\text { Reuters }\end{array}$ & Central bank \\
\hline Mode of Reporting & Electronic & $\begin{array}{l}\text { Electronic, } \\
\text { tape and } \\
\text { publication }\end{array}$ & $\begin{array}{l}\text { Electronic, } \\
\text { tape and } \\
\text { publication }\end{array}$ & $\begin{array}{l}\text { Electronic tape } \\
\text { and publication }\end{array}$ & $\begin{array}{l}\text { Electronic, } \\
\text { tape and } \\
\text { publication }\end{array}$ & $\begin{array}{l}\text { Electronic } \\
\text { and } \\
\text { publication }\end{array}$ & $\begin{array}{l}\text { Electronic } \\
\text { tape and } \\
\text { tublication }\end{array}$ & $\begin{array}{l}\text { Electronic, tape } \\
\text { and publication }\end{array}$ & $\begin{array}{l}\text { Tape and } \\
\text { publication }\end{array}$ & $\begin{array}{l}\text { Electronic, } \\
\text { tape and } \\
\text { publication }\end{array}$ & $\begin{array}{l}\text { Electronic, } \\
\text { tape and } \\
\text { publication }\end{array}$ \\
\hline Confidentiality & Public & Public & Public & Public & Public & Public & Public & Public & Public & Public & Public \\
\hline $\begin{array}{l}\text { Frequency of } \\
\text { Publication }\end{array}$ & Daily & Monthly & Monthly & Monthly & Daily & Monthly & Monthly & Monthly & Annual & Quarterly & Quarterly \\
\hline
\end{tabular}

1/ Central govenment balance is released to the press monthly, about three weeks after the end of the month, and published by the Mimistry of Finance.

y Spanish government debt held by nonresidents is released to the press weekly by the central bank and drawn by staff from Reuters. 


\title{
Staff Report for the 2000 Article IV Consultation Supplementary Information
}

\author{
Prepared by the European I Department \\ Approved by Michael C. Deppler and G. Russell Kincaid
}

October 18,2000

1. This supplement reports on information on economic and financial developments in Spain since the issuance of the staff report for the 2000 Article IV consultation (SM/00/222, $9 / 29 / 00$ ) to the Executive Board. The information does not alter the thrust of the staff appraisal.

2. Consumer price inflation in September rose to 3.7 percent (on a 12-month basis), slightly above the 3.6 percent increase recorded in July and August. Underlying inflation (which excludes energy and unprocessed foodstuffs) held constant at 2.7 percent in September. Producer price inflation declined to 5.1 percent in August (on a 12-month basis), down from 5.5 percent in July. The current account deficit through July equaled 2.8 percent of GDP, versus 2.7 percent through June.

3. On October 5 , the ECB increased its main refinancing rate by 25 basis points to 4.75 percent. Given the continued weakness of the euro, and the uptick in consumer price inflation which diminishes the real impact of the nominal rate increase, it remains the staff's view that monetary conditions in Spain are more accommodative than might be appropriate from a purely Spanish perspective.

4. Some recent indicators support the Staff Report's projection that domestic demand growth would continue to slow over the course of 2000-01. The index of consumer confidence dropped sharply in September, to its lowest level in two years, while registrations of new automobiles fell by 20 percent compared to the same month a year earlier. The index of confidence in the retail sector also declined in September, following a very steep drop in July. In addition, the Ministry of Economy's synthetic indicators of private consumption and goods investment portend slower growth in the third quarter. These declines likely reflect in large part uncertainty arising from very high oil prices.

5. The staff has revised its macroeconomic projections based on updated country information, a revised interest rate path reflecting recent market expectations, and a new baseline for oil prices (some US $\$ 5$ per barrel about the baseline in the published WEO, with an average price of US $\$ 29$ per barrel for 2000). The revised assumptions have no effect on 
projected output growth or inflation in 2000 . However, real GDP is now projected to grow by 3.2 percent in 2001, compared to 3.5 percent in SM/00/222, while headline inflation is forecasted at 2.7 percent, compared to an estimate of 2.4 percent in the staff report. These changes are in line with those produced for other euro area countries, leaving growth and inflation differentials relative to the euro-area averages essentially unchanged in 2001 , relative to the estimates in SM/00/222.

6. Importantly, the revised projections assume that higher oil prices and headline inflation do not lead to a significant loss of wage moderation, and the effects could be considerably greater were this commitment to wane. This emphasizes the need for continued progress in labor market reform, to allow for further reductions in the structural unemployment rate to help forestall the emergence of wage pressures. Data on collective bargaining agreements through September show no indication of an acceleration of wage growth, but the fact that many labor contracts include "safeguard clauses" to compensate workers when inflation exceeds the official forecast means that some of this year's higher-than-expected inflation will spill over into wage growth next year.

7. The authorities have indicated that they expect to overperform somewhat on the revised fiscal deficit target of 0.4 percent of GDP for this year, although they have not quantified the extent of the anticipated overperformance. They have reached agreement with the agricultural and transportation sectors on a package of tax measures valued at about 0.1 percent of GDP to compensate them for increased operating costs related to the higher price of oil. Notably, these measures do not reduce specific or ad valorem taxes on petroleum products, although the specific petroleum tax will not increase next year. ${ }^{1}$ The net impact of these measures on the budget is likely to be minimal, as the staff anticipates they will be largely offset by higher VAT revenues on oil products. Through end-August, the deficit of the State government on a national accounts basis stood at 0.2 percent of GDP, compared to an annual target of 0.6 percent.

8. The 2001 budget was presented to Parliament in late September. As foreshadowed in the Staff Report, the proposed budget calls for overall public sector balance, with a social security surplus of 0.3 percent of GDP offsetting a State government deficit of the same magnitude. The budget is based on real output growth of 3.6 percent, compared to the revised 3.2 percent now projected by the staff.

9. These revisions do not alter the staff's policy advice, which was to welcome the decision to accelerate fiscal consolidation this year and next, and to highlight that a move to structural balance in 2001 was both feasible and desirable. Given the likelihood that the 2000 deficit will be below the revised target, and that the projected decline in real output growth

\footnotetext{
${ }^{1}$ In previous years, the specific tax had increased each year in line with the official inflation target.
} 
next year will be offset in nominal terms by expected higher inflation, no additional measures should be required to achieve nominal fiscal balance. Indeed, structural balance should also remain within reach: the actual fiscal surplus required to achieve structural balance would be very modest (on the order of about $1 / 4$ percent of GDP), implying only a slight improvement over the budget target 


\section{INTERNATIONAL MONETARY FUND}

Public Information Notice

EXTERNAL

RELATIONS

DEPARTMENT

Public Information Notice (PIN) No. 00/98

FOR IMMEDIATE RELEASE

November 15,2000
International Monetary Fund

$70019^{\text {th }}$ Street, NW

Washington, D. C. 20431 USA

\section{IMF Concludes Article IV Consultation with Spain}

On October 20,2000, the Executive Board concluded the Article IV consultation with Spain. ${ }^{1}$

\section{Background}

Spain's economic performance has been impressive in recent years, reflecting increased competitiveness, as well as the favorable impact on interest rates and confidence of decisive macroeconomic policies that reduced the general government deficit by nearly 4 percent of GDP between 1996 and 1999 and qualified Spain for Stage 3 of monetary union. Over the last three years real output growth has averaged more than 4 percent, with domestic demand growing by about 51/2 percent in both 1998 and 1999. Although the pace of domestic demand growth has moderated slightly in recent quarters, this has been offset by a renewed pickup in exports. Nevertheless, both private consumption and investment growth remain robust.

Aided by significant labor market reforms and notable wage moderation, strong output growth has led to a sharp increase in employment. The unemployment rate has dropped from over 24 percent in 1994 to 14 percent in mid-2000. However, substantial disparities in unemployment rates exist across regions and age groups and between genders. New contract wages rose by about 3 percent through August 2000, compared to about 21/2 percent in 1999.

As throughout much of the euro area, headline consumer price inflation has risen in recent months, reflecting in large part the impact of higher oil prices. Underlying consumer price inflation, which excludes energy and nonprocessed foodstuffs, has been relatively stable for

\footnotetext{
${ }^{1}$ Under Article IV of the IMF's Articles of Agreement, the IMF holds bilateral discussions with members, usually every year. A staff team visits the country, collects economic and financial information, and discusses with officials the country's economic developments and policies. On return to headquarters, the staff prepares a report, which forms the basis for discussion by the Executive Board. At the conclusion of the discussion, the Managing Director, as Chairman of the Board, summarizes the views of Executive Directors, and this summary is transmitted to the country's authorities. In this PIN, the main features of the Board's discussion are described.
} 
the last year. However, inflation has exceeded the euro-area average by $1 / 2$ to $1 \frac{1}{2}$ percentage point since 1997. Much of the inflationary impulse comes from the services sector, where annual rates of price increase have averaged 3.5 percent over the last 12 months, compared to 1.6 percent for the euro area.

Nevertheless, despite higher than euro-area average CPI inflation, competitiveness in world markets remains strong, although a persistent inflation differential would erode competitiveness within the monetary union over the medium term. Both $\mathrm{CPI}$ and unit labor cost-based real effective exchange rates remain at the levels following the devaluations of 1992-93, although to some extent this reflects the weak euro. The continuing depreciation of the euro has left monetary conditions at their most accommodative level in many years. Asset prices have grown solidly in recent years, but more slowly than in some other euro-area countries.

The fiscal deficit fell to 1.1 percent of GDP in 1999, substantially better than the initial target of 1.6 percent. In 2000 fiscal consolidation is again running ahead of track, with the original deficit target of 0.8 percent of GDP having been officially revised down to 0.4 percent of GDP. The 2001 budget aims at fiscal balance, one year ahead of the schedule laid out by the authorities in their Stability Program. The improved fiscal position in recent years reflects not only cyclical factors but also tight expenditure control and strong revenue buoyancy.

\section{Executive Board Assessment}

Executive Directors praised the authorities for their impressive macroeconomic policy management since Spain's entry into the EMU, which-along with labor and product market reforms and wage moderation-has allowed it to enjoy an unprecedented combination of rapid output and employment growth, with historically low inflation. While the authorities duly deserve praise for these achievements, Directors urged them to be alert to possible risks over the medium term, and to take the present opportunity to press ahead with fiscal consolidation and further structural reforms.

Directors noted that economic growth is expected to remain strong in the remainder of 2000 and in 2001. While there are risks of overheating in the economy, they agreed that such concerns are likely to abate somewhat in the coming year, as domestic demand growth slackens in response to higher oil prices and interest rates. Directors highlighted, however, that Spain's persistent inflation differential relative to the euro-area average could erode the economy's currently strong competitive position in the medium term. In this connection, they underscored the importance of continued wage moderation, noted the risks due to the extensive continued use of indexation, and recommended a progressive reduction in indexation practices.

Directors welcomed the authorities' decision to reduce the fiscal deficit target for 2000 to half of its initial level and to achieve balance in 2001, ahead of the schedule established in Spain's Stability Program. This accelerated fiscal consolidation prudently takes advantage of robust economic growth to realize medium-term objectives. It also serves as a counterweight against 
monetary conditions that are unduly accommodative from a purely Spanish perspective, despite recent interest rate increases by the European Central Bank. Indeed, most Directors recommended that, if growth and revenues remain buoyant, the authorities should endeavor to achieve a small nominal surplus next year, i.e. approximately structural balance. Some Directors, however, stressed that further fiscal consolidation should not take place at the cost of needed infrastructure improvements.

Directors welcomed the progress that has been achieved in the labor market, as evidenced by the rapid growth of employment. Nevertheless, high unemployment and low participation rates remain a pressing economic problem, and labor mobility needs to be encouraged. The 1997 labor market reform demonstrated that reducing dismissal costs was key to stimulating employment growth, and Directors urged further progress in this direction. Reforms to encourage greater use of part-time employment would also be welcome, as it could prove an effective vehicle for increasing the participation of women and the young in the workforce. They also expressed concern about persistent disparities in regional unemployment rates, and recommended appropriate cooperative action by national and regional authorities and private sector agents, including wage bargaining that was more responsive to local market conditions; more effective training, which would be important in upgrading skills and easing integration in the labor force; and reforms to property markets and rental housing. While Directors praised the authorities' commitment to a cooperative approach to labor market reform, they felt, however, that the search for consensus should not be allowed to unduly delay necessary reforms.

Directors welcomed the package of product market measures introduced in June 2000, which sends a clear signal of the authorities' commitment to reform. These initiatives should enhance competition in such key sectors as telecommunications, energy, pharmaceuticals and retail sales, and should encourage investment in new technologies, particularly among small and medium enterprises. Directors recommended that consideration be given to more fully liberalize opening hours and calendars and remove remaining restrictions on retail competition. Further measures to enhance competition in key sectors like electricity and water might also be required.

Directors noted that population ageing will put increasing pressure on spending-especially for pensions - in the coming decades. They considered that the prudent course will be to address these pressures through a combination of fiscal and structural policies that foster more rapid growth over the medium and long term. In this respect, Directors recommended that the social security system be allowed to continue to accumulate a surplus, with the rest of the public sector moving at least to overall balance. In addition, measures should be adopted to ensure a closer link between pension benefits and contributions, particularly in the context of the upcoming renewal of the Pacto de Toledo, the multi-year agreement that spells out pension reforms.

Directors also noted that-with the transfer of expenditure responsibilities to regional governments now largely complete-the upcoming renegotiation of financing arrangements with regional governments provides an opportunity to develop a more permanent financial 
framework for fiscal decentralization. They suggested that future reforms could usefully widen the revenue bases of regional and municipal governments, so as to reduce their variability and eliminate distortions in property markets resulting from the heavy reliance of municipal governments on revenues from property. Directors stressed that local autonomy- and adequate solidarity to safeguard public services throughout Spain-should be complemented by commitments to protect national fiscal goals. In this connection, they stressed the synergies that could be unlocked over the longer term by a forward-looking fiscal strategy that includes effective medium-term expenditure control.

Directors praised the commitment of regulators to keep pace with developments in financial markets. In particular, they welcomed the new provisioning requirements introduced by the Bank of Spain, and supported increased coordination with foreign supervisors. The provisioning requirements, together with a continued conservative accounting treatment of banks' overseas assets, should allow banks' balance sheets to weather declines in portfolio quality that may arise from economic cycles at home or abroad.

Directors encouraged the authorities to increase their funding for official development assistance towards the UN target.

Public Information Notices (PINs) are issued, (i) at the request of a member country, following the conclusion of the Article IV consultation for countries seeking to make known the views of the IMF to the public. This action is intended to strengthen IMF surveillance over the economic policies of member countries by increasing the transparency of the IMF's assessment of these policies; and (ii) following policy discussions in the Executive Board at the decision of the Board. As part of a pilot project, the staff report for the 2000 Article IV consultation with Spain is also available. 
Spain: Selected Economic Indicators

\begin{tabular}{|c|c|c|c|c|c|}
\hline & 1996 & 1997 & 1998 & 1999 & 200011 \\
\hline \multicolumn{6}{|l|}{ Real economy (change in percent) } \\
\hline GDP & 2.4 & 3.9 & 4.3 & 4.0 & 4.1 \\
\hline Domestic demand & 1.9 & 3.4 & 5.6 & 5.5 & 4.5 \\
\hline $\mathrm{CPI}$ (average) & 3.6 & 2.0 & 1.8 & 2.3 & 3.2 \\
\hline Unemployment (in percent) & 22.2 & 20.8 & 18.8 & 15.9 & 14.0 \\
\hline Investment 2 / & 21.9 & 22.2 & 23.2 & 24.7 & 26.4 \\
\hline Saving $2 /$ & 21.9 & 22.6 & 23.0 & 22.5 & 23.4 \\
\hline \multicolumn{6}{|l|}{ Public Finance (in percent of GDP) } \\
\hline Central government balance & -4.3 & -2.9 & -2.3 & -0.9 & -0.3 \\
\hline General government balance & -4.9 & -3.2 & -2.6 & -1.1 & -0.4 \\
\hline Structural primary balance $3 /$ & 1.8 & 2.6 & 2.0 & 2.3 & 2.4 \\
\hline Gross general government debt & 68.1 & 66.7 & 64.6 & 63.3 & 62.8 \\
\hline \multicolumn{6}{|l|}{ Interest Rates (annual average) } \\
\hline Three-month interbank rate & 7.5 & 5.4 & 4.2 & 2.9 & $\ldots$ \\
\hline 10-year government bond rate & 8.7 & 6.4 & 4.8 & 4.7 & $\ldots$ \\
\hline \multicolumn{6}{|c|}{ Balance of Payments (in percent of GDP) } \\
\hline Current account balance & 0.0 & 0.4 & -0.2 & -2.1 & -2.9 \\
\hline Trade balance & -2.6 & -2.3 & -3.2 & -4.9 & -6.2 \\
\hline \multicolumn{6}{|c|}{ Fund position (SDR billions, August 31, 2000) } \\
\hline Holdings of currency & & & & & 2.1 \\
\hline Holdings of SDRs & & & & & 0.3 \\
\hline Quota & & & & & 3.0 \\
\hline \multicolumn{6}{|l|}{ Exchange rates } \\
\hline Exchange rate regime & Member & Europ & Econon & d Mon & ry Union \\
\hline Nominal effective rate $(1990=100)$ & 80.9 & 77.2 & 76.9 & 75.6 & $\ldots$ \\
\hline Real effective rate $(1990=100)$ & 89.2 & 85.2 & 85.2 & 84.8 & 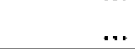 \\
\hline
\end{tabular}

Sources: Bank of Spain; Fund staff projections.

1/ IMF staff projections.

2/ In percent of GDP.

$3 /$ Equal to the general government balance excluding interest expenditure and adjusted for shortrun deviations from long-run output growth. Expressed as percent of potential GDP. For 2000, excludes revenues from the auction of mobile telephone licenses (estimated at 0.1 percent of GDP). 


\section{Statement by Jose Luis Pascual, Advisor to the Executive Director for Spain October 20, 2000}

1. My Spanish authorities want to express their sincere appreciation to the staff for the candid and constructive dialogue during the mission and for the balanced report prepared for this occasion. They think that it appropriately reflects the thrust of the conversations and the main issues of discussion.

\section{Recent Developments and Short-Term Outlook}

2. Since there are no significant differences between the staff and my authorities, I will not review economic conditions. Economic performance has continued to be successful, maintaining the strong output growth and job creation of previous years, while keeping inflation relatively subdued, thanks to the responsible behavior of economic agents and enhanced competition in the economy. The authorities have persevered with a strategy aimed at maintaining an environment conducive to growth by accelerating the fiscal consolidation, implementing a gradual but sustained structural reform program, and preserving a climate of dialogue with economic and social agents.

3. While there are some minor differences between the staff's and the authorities' forecasts, they have not impact on the nature of the conclusions reached in the report. The authorities have opted to be slightly more conservative than the staff in their assumptions, committed to overachieve the targets under normal circumstances, aware of the importance of preserving the credibility so difficulty earned during the past years. But again, the differences are not significant and they do not affect the conclusions on the economic policy to be followed.

4. In the view of some, the main concern on the short term is the risk of overheating and the sudden and sharp corrections it could entail if it is not adequately addressed. We do not think the situation is worrisome yet. In common with the staff, my authorities believe that the signs are mixed. There are no clear signs that augur a burst or sudden changes in relevant prices that could significantly affect agent's expectations. Although headline CPI has reached relatively high levels during the last months, core inflation and wages remain stable and subdued, structural reforms have increased output potential, and asset prices are, in the view of most, not far from fundamentals. This, however, does not mean that the authorities can relax in keeping main indicators in check. Caution is warranted and they are committed to remain vigilant and adopt whatever measures become needed to preserve the stable environment that has supported the prosperity the economy is experiencing.

5. Under these circumstances, the policy mix is based on fiscal restraint, advancing the balanced budget target by one year to 2001. This objective will be compatible with an increase in capital spending by concentrating the bulk of the adjustment on current spending. Revenue growth will also help and any additional windfall revenue will be dedicated to further improve public accounts. This target should not be incompatible with the staff's structural balanced budget target. 


\section{Medium-Term Policies}

6. My Spanish authorities do not see much room for discretionary measures of finetuning to deal with excess demand within the present institutional framework. Monetary policy is now conducted with reference to the entire Euro area and fiscal policy is not an effective tool to manage demand in the very short term. Although they recognize that fiscal policy can affect demand to some limited extent, they prefer to avoid fine-tuning and rather focus on more medium-term objectives that include supply-side considerations. Demand management is important but, from their perspective, it is even more important to create the conditions to increase the economy's growth potential by enlarging supply.

7. In this light, they believe that, in the present framework, the best way to manage the economy is by designing a medium-term economic program ("Programa de Estabilidad") to be implemented gradually. This is the best way to gain credibility, demonstrate commitment, and provide the private sector with a stable economic environment.

8. Based on these considerations, the general strategy consists of actions on fiscal policy oriented to medium-term sustainability targets and structural reforms aimed at increasing flexibility in the economy. More precisely, there would be four main fields of action:

- Continued fiscal consolidation, based in the containment of current expenditures.

- Deepened tax reforms to improve the efficiency and equity of the tax system.

- Further liberalization of the economy through advancements in structural reforms, privatization, deregulation, administrative decentralization, and strengthened surveillance of competition.

- Social dialogue to advance the reform of the labor market.

9. In the fiscal field, the aim is to accelerate as much as possible the drive to place public accounts on a sounder footing. This would create room for maneuver that should allow the automatic stabilizers to work freely in the event of a downturn in growth; provide the authorities a certain degree of freedom to act discretionally if the situation demands so; and face the remaining structural challenges to the public accounts in better conditions. Yet, this objective is not to be understood in absolute terms, no matter the means or the consequences. Fiscal consolidation is crucial to preserve the gains of the past efforts, but it should be reconciled with the need for high public investment and with the authorities" determination to capitalize on the benefits from a further reduction in the tax burden in the medium run.

10. Two issues are, in the staff's view, crucial to ensure the long-term sustainability of the public sector: the pension system, and inter-governmental fiscal relations. Both issues have been already addressed by the authorities in prior years. There is room for improvement though. On the pension system, the discussions to be opened when the "Pacto de Toledo" is reviewed will doubtless serve to advance in areas where improvements are still possible, i.e., increasing the relation between benefits and contributions, and discouraging early retirement. 
By the same token, my authorities intend to save present and future Social Security's surpluses in a so-called Reserve Fund to be prepared for future liabilities.

11. On the new system of financing the lower levels of government, despite the apparent controversy, there is a general consensus on the need for all layers of government to contribute to achieving the prescriptions of the Stability and Growth Path. My Spanish authorities have taken due note of the staff's suggestion and will work to get a new, more stable, and generally accepted financing framework with a higher degree of fiscal coresponsibility. They are also working on a new financing model for local entities that-by being less dependent on property taxes-will be less distortive for economic activity and labor mobility.

12. One of the main elements of the current strategy is the gradual process of tax reform which has been, and will continue to be, closely linked to the evolution of fiscal deficits. The main targets of this strategy are: (1) to reduce the tax wedge; (ii) to foster economic growth and job creation; (iii) to promote entrepreneurial activity by economic agents; (iv) to encourage national savings; and (v) to promote small and medium size enterprises, given their high flexibility and their leverage for job creation.

13. As for structural reforms, the authorities remain convinced that additional liberalization and flexibility is needed in both product and factor markets. The aim is to improve the allocation of resources, enhance competition, and preserve competitiveness, while adding new flexibility to the economy to enable it to cope with, and take advantage of, crucial technological changes and the deeper integration of markets.

14. Despite the very positive evolution of major variables in the labor market, there is a broad consensus across the Spanish society on the need to reform the functioning of this market further, in particular to add more flexibility. My authorities strongly believe that the consensual approach followed so far has shown its advantages and they intend to keep using it. Social peace is not only cost-saving but also investment-enhancing by fomenting stability. We are sure that part of the increase in FDI experienced during the last two years is a consequence of this cooperative climate.

15. Job creation has been intense during the last two to three years, due surely both to the 1997 reform and to the very favorable prospects employers have experienced. There remains, however, much to be done to address the high level of unemployment among youth and women and to increase the participation rate to levels more consistent with the general development of the country. Higher participation will also be key to address the challenges the country will experience from population aging in the future. My authorities have contemplated measures on both sides, supply and demand. On the supply side, additional resources have been appropriated in the new budget to improve skills and enhance the ability of the unemployed to adapt to new labor demands. On the demand side, in the light of the experience, the authorities are considering new initiatives to reduce dismissal costs, simplify the unduly complex system of social security subsidies, and increase labor mobility. 
16. The authorities' commitment to product market reforms is absolute. In their view, this is an essential part of the only viable way to achieve the faster path of growth the convergence process demands. Last June, soon after the new government officials had been sworn into their posts, a new package was introduced to advance in the deregulation process and to send a clear message of the authorities' intentions with regard to liberalization and effective competition. My authorities concur with the staff in admitting that there is some scope for improvement in some areas as pharmacy competition, retail distribution, and opening hours. They will address them in due time. They point out, however, that the gradual approach followed so far has been successful in achieving a relatively peaceful, fruitful and steady liberalization process.

17. From the outset, my Spanish authorities have paid great attention to the profound changes the Spanish financial system has been experiencing. Such changes have been important not only in the banking sector, but also in the capital markets. My authorities, fully aware of the importance of having appropriate access to capital markets for new companies and risky ventures, have promoted the creation of new markets and specific instruments to satisfy their financial needs.

18. The extensive investment in Latin America has forced my authorities to monitor very closely developments in the banking sector during the last several years. In their view, the financial health of the system is very sound. And this is so, not only because the economic performance of the region has improved, but also because prudential measures were adopted to preserve the good health of the system. They point in particular to the close monitoring of internal reserves, the accelerated amortization of goodwill, the coordination of supervisory activities with other involved supervisors and the establishment of a specific unit within the supervision department to monitor this expansion.

19. Finally, on the issue raised by the staff regarding the need to establish a unified financial sector supervision either nationally or in the Euro area, my authorities are clear: there is no need for experiments when the present system has worked well. There are currently mechanisms in place that ensure appropriate coordination among supervisors. This, nonetheless, does not mean that if it is demonstrated that changes are required, they will be opposed to more formal arrangements. Simply, they do not see the need right now. 